by Emilio Saccani ${ }^{1}$, Yildirim Dilek ${ }^{2}$, Michele Marroni ${ }^{3}$, Luca Pandolfi $^{3}$

\title{
Continental margin ophiolites of Neotethys: Remnants of Ancient Ocean-Continent Transition Zone (OCTZ) lithosphere and their geochemistry, mantle sources and melt evolution patterns
}

\footnotetext{
${ }^{1}$ Dip. di Fisica e Scienze della Terra, Univ. di Ferrara, Via Saragat 1, 44123 Ferrara, Italy. Corresponding author E-mail: sac@ unife.it

${ }^{2}$ Dept. of Geology \& Environmental Earth Science, Miami University, Oxford, OH 45056, USA

${ }^{3}$ Dip. di Scienze della Terra, Univ. di Pisa, Via S. Maria 53, 56126 Pisa, Italy
}

DOI: $10.18814 /$ epiiugs/2015/v38i4/82418

We present an overview of the geology, geochemistry and petrogenesis of continental margin ophiolites (CMO), which represent the lithospheric remnants of riftgenerated paleo ocean - continent transition zones (OCTZ) in orogenic belts. The igneous stratigraphy and geochemical signatures of Neotethyan CMOs reflect the extent of geochemical heterogeneity, partial melting degrees, and melt evolution patterns in the continental lithospheric mantle prior to the onset of seafloor spreading in rifted margins. Basaltic rocks of the Jurassic CMOs in the External Ligurian units of the Northern Apennines have N-MORB and G-MORB affinities with strong HREE/MREE depletion, and represent the products of partial melting of a heterogeneous subcontinental lithospheric mantle containing small volumes of garnet pyroxenite layers. These extrusive rocks were erupted directly on the exhumed fertile spinel lherzolites of Adria during its OCTZ evolution. Volcanic rocks of the Triassic CMOs in the Albanide-Hellenide orogenic belt are represented by calc-alkaline suites; alkaline basalts and subordinate trachybasalts, trachyandesites, and trachytes; transitional to sub-alkaline plume-type PMORB basalts; sub-alkaline enriched, E-MORB basalts; and, sub-alkaline N-MORB basalts. Upper mantle peridotites are not exposed. Magmas of these extrusive rock associations were derived from compositionally distinct mantle sources, which were affected by previous subduction and plume events in the geological history of the region. The CMOs in the Zagros orogenic belt include metamorphosed lherzolites with gabbro and mafic dike intrusions, which show N-MORB and GMORB affinities. Basalts and basaltic andesites making up the majority of the Zagros volcanic sequences have E-MORB and P-MORB affinities, whereas minor alkaline rocks that are composed of basalts, trachybasalts and trachytes display OIB signatures. The mantle sources of the Zagros CMOs were progressively enriched in Th and $\mathrm{Nb}$. The OIB component of the mantle beneath the Zagros OCTZ was derived from previous plume events during the early Carboniferous, when Paleotethys was undergoing its rift-drift tectonics. The observed differences in the igneous stratigraphy and geochemical affinities of these Neotethyan CMOs are a result of extreme mantle heterogeneity caused by previous subduction and plume events during the Wilson Cycle evolution of the older Paleotethys.

\section{Introduction}

Ophiolites represent fragments of ancient oceanic lithosphere (Dewey and Bird, 1971; Coleman, 1971) that were incorporated into continental margins during a variety of plate interactions (see Dilek and Furnes, 2011). They are commonly found along suture zones, which mark major boundaries between amalgamated plates or accreted terranes (Dilek, 2003a; Lister and Forster, 2009). Ophiolites record magmatic activities and tectonic processes associated with the construction and consumption of ancient oceanic basins from their rift-drift and sea floor spreading stages to subduction initiation 
and final closure phases. Magmatism during each of these phases produces ultramafic to mafic and evolved rock assemblages, which have distinct internal structures, geochemical afûnities, and age ranges, depending on their original tectonic setting of formation. The geological record of the Wilson cycle evolution of ocean basins is, therefore, partially preserved in most ophiolite complexes along suture zones.

The Penrose definition of an ophiolite is a "distinctive assemblage of ultramafic and mafic rocks" that includes, from bottom to top, tectonized peridotites, cumulate peridotites, and pyroxenites overlain by layered gabbros, sheeted basaltic dikes, a volcanic sequence, and a sedimentary cover ('Penrose-type igneous sequence'; Anonymous, 1972, p. 24). An ophiolite may be incomplete or tectonically dismembered, and it can also be metamorphosed. Dilek and Furnes $(2011,2014)$ have recently argued that this original Penrose definition of ophiolites (Anonymous, 1972) is inadequate to explain the significant variations in the internal structures, compositions, geochemical signatures, and emplacement mechanisms of ophiolites. They have introduced a more detailed classification based on the characteristic internal structures, geochemical fingerprints, and regional tectonics of ophiolites. Among the most important parameters controlling the magmatic evolution of different ophiolite types are: (1) the rate, geometry and nature of seafloor spreading, (2) the proximity of a spreading center to a plume or trench, (3) mantle composition, temperature and fertility, and (4) the availability of fluids (Dilek and Furnes, 2014).
In their new classification, Dilek and Furnes $(2011,2014)$ have defined the Continental Margin (CM) ophiolites as mafic-ultramafic and sedimentary rock assemblages that formed during the continental breakup and embryonic oceanic crust generation at ocean-continent transition zones (OCTZ). These ophiolites do not have the ideal Penrose-type igneous sequence and generally include fertile peridotites of continental lithospheric mantle that are directly overlain by basaltic lavas and hemi-pelagic sedimentary rocks. Basaltic rocks display a normal (N-) MORB geochemistry characterized by marked garnet signatures commonly typified by depletion in heavy rare earth elements (HREE) with respect to middle rare earth elements (MREE). Saccani (2015) used the term G-MORB (garnet-influenced MORB) for identifying this basaltic sub-type, which can easily be distinguished from typical N-MORBs using Ce-Dy-Yb systematics (see Fig. 8 in Saccani, 2015). The petrogenesis of CM ophiolites involves small degrees of partial melting of little depleted lithospheric mantle and slowly uprising asthenosphere in magma-poor, "cold rift" tectonic settings (Dilek et al., 1998). Thus, CM ophiolites constitute an important end-member of the entire ophiolite spectrum (Dilek, 2003a).

Some of the best examples of CM ophiolites include the Jurassic ophiolites in the Ligurian units of the Northern Apennines (e.g., Montanini et al., 2008; Marroni and Pandolfi, 2007), Alpine Corsica (Durand-Delga, 1984; Malavieille et al., 1998; Saccani et al., 2008a), and the Western Alps (Lagabrielle and Cannat, 1990; Desmurs et al., 2002; Rampone et al., 2005; Manatschal and Müntener, 2009; Festa

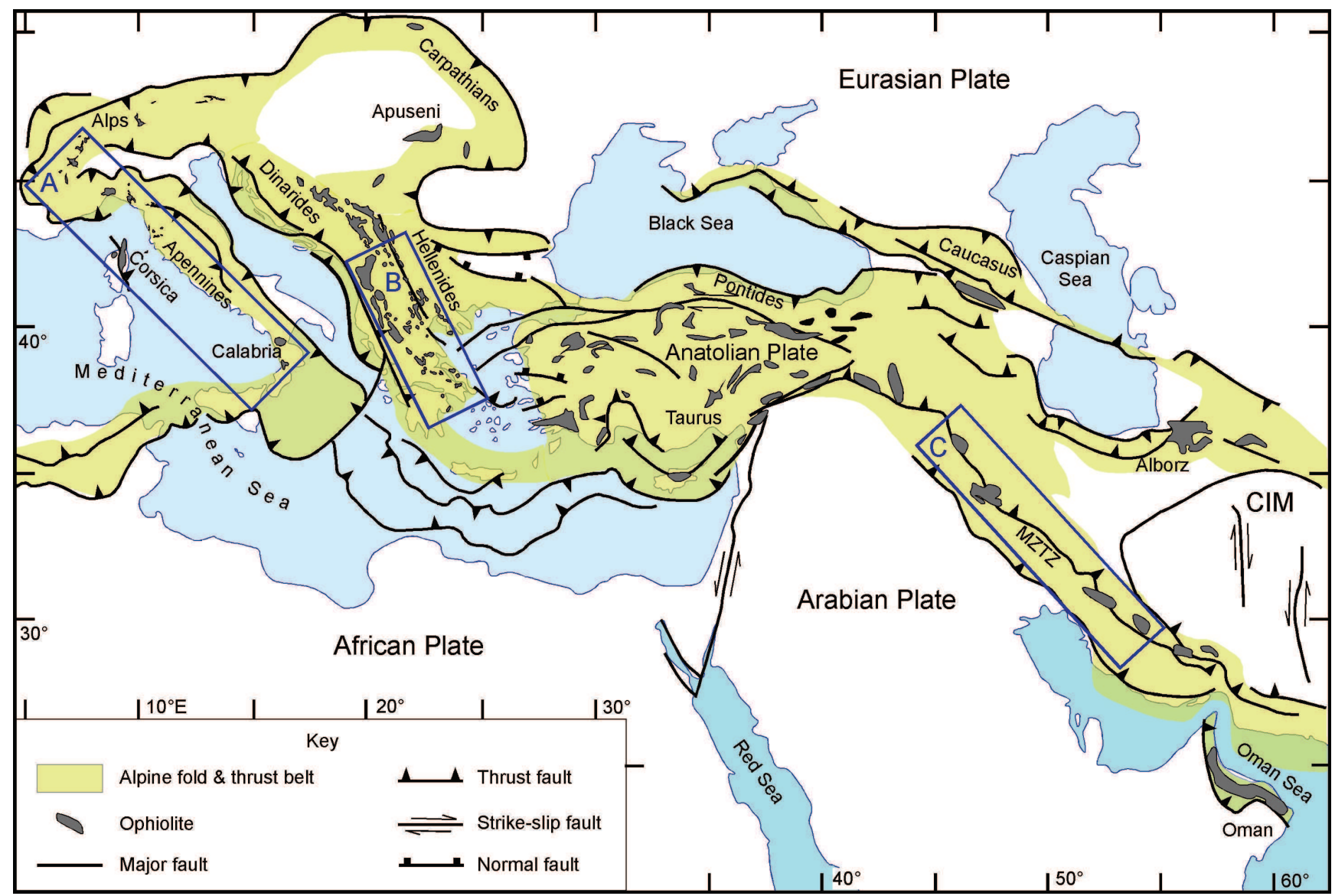

Figure 1. Distribution of major ophiolitic complexes in the Alpine orogenic belts from the central Mediterranean area to the Oman Sea. The major tectonic lineaments are also shown. Boxes indicate the investigated areas. A: Western Tethys ophiolites (Alps-Corsica-ApennineCalabria); B: Albanide-Hellenide ophiolites; C: Zagros ophiolites. MZTZ: Main Zagros Thrust Zone, CIM: Central Iranian Microcontinent. 
et al., 2015; Balestro et al. 2015; ), and the early Cretaceous DongbaPurang ophiolites in southern Tibet (Liu et al., 2015; Yang and Dilek, 2015). However, many more CM ophiolites are yet to be documented in the Phanerozoic and Precambrian orogenic belts through systematic structural field and geochemical studies. Most CM ophiolites are commonly multiply deformed and metamorphosed, undergone subduction-exhumation processes, and/or incorporated into subophiolitic mélanges as blocks or thrust sheets (Dilek, 2003a; Dilek and Robinson, 2003). Thus, recognition of CM ophiolites and associated tectonostratigraphic units in continental collisional zones may be particularly difficult at best.

In this paper we examine the geological and geochemical characteristics of continental margin ophiolites of Neotethyan origin (Fig. 1), and discuss their melt evolution in OCTZs. We first review the geological and magmatic features of rifted continental margins. We then describe the geology and geochemistry of three continental margin ophiolites in different domains of the Neotethyan realm, in the Western Alps-Alpine Corsica-Northern Apennines (i.e., the Western or Alpine Tethys), in the Albanide-Hellenide belt (PindosMirdita ocean basin), and in the Zagros orogenic belt in Iran. We next compare and contrast various petrogenetic models for the formation of these ophiolites, focusing on their mantle sources and melt evolution. We think that this overview of continental margin ophiolites will help us differentiate similar mafic-ultramafic rock associations of ancient OCTZs that have been otherwise unrecognized in collisional orogenic belts.

\section{Rifted Continental Margins}

Rifted continental margins and OCTZs have been divided into "non-volcanic" (Iberia-type) and "volcanic" (East Greenland-type) types, based largely on the study of the Central and North Atlantic regions by the deep Ocean Drilling Program (e.g., Whitmarsh et al. 2001). Non-volcanic rifted margins are invariably magma-poor and are considered to have undergone extension that varied vertically and laterally both in space and time. Simple shear (Wernicke, 1981) and detachment (Lister et al., 1991) models have been proposed to interpret this depth-dependent extension (Royden and Keen, 1980; Kusznir and Karner, 2007), and to explain the differences observed in the tectonic architecture of modern magma-poor rifted continental margins. The first step in the evolutionary path in these models (Fig. 2a) is the formation of offset rift basins via distributed deformation (Huismans and Beaumont, 2007; Beaumont and Ings, 2012; Chenin and Beaumont, 2013). The subsequent extensional deformation becomes focused leading to the development of a major basin bounded by listric faults. This rifting process is characterized by a profound asymmetric geometry and formation of transitional zones with variable width where the thickness of the continental crust decreases abruptly. Little surface magmatism occurs during continued rifting. The resulting magma-poor continental margins and the related OCTZs are thus characterized by exhumation of serpentinized continental mantle lithosphere as well as high- grade metamorphic rocks of lower crust (Fig. 2b). The best modern analogue for such magma-poor rifted margins is the Iberia-Newfoundland conjugate margins pair (e.g. Péron-Pinvidic and Manatschal, 2009; Van Avendonk et al., 2009; Sibuet and Tucholke, 2013). A very thin oceanic crust may form in the initial stages of spreading, following the continental breakup.

The majority of rifted continental margins worldwide are
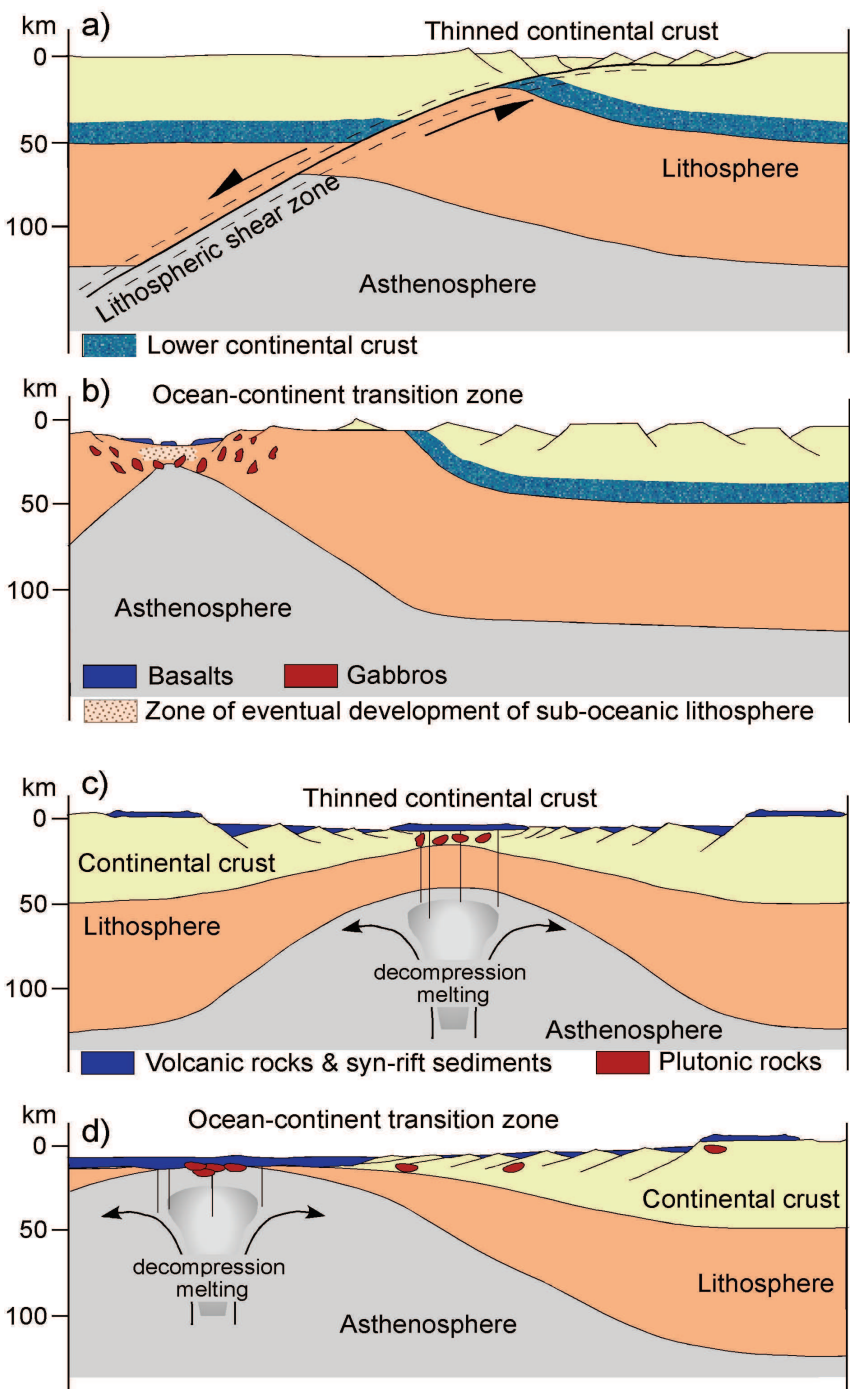

Figure 2. Simplified rift-drift models for magma-poor $(a, b)$ and volcanic $(c, d)$ continental rifted margins.

represented by volcanic types, which are generally characterized by thick wedges (up to $15 \mathrm{~km}$ ) of volcanic flows (Hinz, 1981; Mutter et al., 1982; Menzies et al., 2002; Skogseid, 2001) that form seaward dipping seismic reflectors. The rifting mechanism produces a crustal architecture that shows an overall symmetry (Fig. 2c). Crustal thinning typically occurs over a comparably short distance in the order of 50 to $100 \mathrm{~km}$. As a consequence, the volcanic rifted continental margins are typically devoid of exposures of subcontinental mantle or highgrade lower crust. The lack of strong passive margin subsidence during and after breakup and the presence at depth of a dense lower crustal body with anomalously high seismic velocities $(\mathrm{Vp}>7.1 \mathrm{~km} / \mathrm{s})$ are also characteristic features of volcanic rifted margins (Planke et al., 1991; Eldholm et al., 2000). Volcanic rifted margins are commonly associated with large igneous provinces (LIPs) onshore (Fig. 2c), and major regional dike swarms and sills (Coffin and Eldholm, 1994; Dilek, 2003b). Examples of LIPs associated with volcanic rifted margins include the North Atlantic Igneous Province (e.g., Kerr, 1994; Storey et al., 2007) and the Kerguelen-India-Antarctica-southwestern Australia area (e.g., Coffin et al., 2002). As the regional extensional stress regime remains active and rifting continues, a seafloor spreading system becomes established following the crustal breakup whereby normal oceanic crust is produced (Fig. 2d). 


\section{Continental Margin Ophiolites of Western Tethys}

\section{Regional Geology}

The ophiolites in the Northern Apennines, Alpine Corsica, and Western Alps (Fig. 1) represent the remnants of the Western Tethys Ocean (also known as Liguria-Piemonte Ocean or Alpine Tethys). This oceanic basin developed in a western seaway of the Tethyan realm between Europe-Corsica and Adria continental domains after the Triassic to middle Jurassic rifting and the middle to late Jurassic seafloor spreading episodes (Manatschal and Müntener, 2009 and quoted references). The Western Tethys oceanic basin has been interpreted as a narrow ( $<600 \mathrm{~km}$-wide) seaway, developed as a result of ultra slow spreading (e.g., Marroni and Pandolfi, 2007). Major reorganizations in plate motions and plate boundary configurations within the Tethyan system in the late Cretaceous led to oblique convergence between Europe-Corsica and Adria that resulted in the development of an intra-oceanic subduction zone within the Western Tethys oceanic basin (e.g., Marroni et al., 2010 for the Northern Apennines and Compagnoni, 2003 for the Western Alps). Following the terminal closure of the Western Tethys oceanic basin in the early Tertiary, Adria and Europe collided leading to the development of a thick, doubly-verging orogenic wedge in the Alpine-Apennine mountain system. Continental margin ophiolites were thrust eastwards in the Northern Apennines and westward in the Western Alps and Alpine Corsica during this continental collision stage.

The ophiolites in the Western Alps and the Schistes Lustrés of Corsica display eclogite to blueschist facies metamorphic overprint as a record of the subduction events in the Western Tethys oceanic basin. In contrast, the ophiolites in the Internal Ligurian (IL) units of the Northern Apennines, and Alpine Corsica (Pineto, Balagne and Rio Magno) are only weakly metamorphosed but strongly deformed. These features are interpreted to have resulted from shallow level, low-P accretion (Marroni and Pandolfi, 2003; Marroni et al., 2004; Meneghini et al., 2009). The upper mantle peridotites, gabbros and basalts in the External Ligurian (EL) units occur, however, in a different structural position. They occur as blocks embedded in a Santonian-Campanian sedimentary mélange, which also includes fragments of granitoids and mafic granulites of the Hercynian continental crust (e.g. Casanova and Ragola Complexes; Marroni et al., 2001).

\section{Geochemistry}

\section{Mantle lherzolites}

Studies of the ophiolites in the Western Alps and the Northern Apennines have revealed high degrees of chemical and isotopic heterogeneity in their upper mantle peridotites (Rampone et al., 1995, 1998, 2005, Montanini et al., 2006; Rampone and Hofmann, 2012). These findings led to the recognition of two major types of upper mantle sequences in the Ligurian units of the Northern Apennines: the mantle peridotites of the EL units, and the mantle peridotites of the IL units.

The upper mantle peridotites of the EL units consist mainly of fertile spinel lherzolites, representing the subcontinental lithospheric mantle exhumed during the early stages of continental rifting, which led to the opening of the Jurassic Western Tethys oceanic basin. The isotopic ages of these peridotites range between $2.4 \mathrm{Ga}$ and $780 \mathrm{Ma}$, and their $\mathrm{Sr}$ and $\mathrm{Nd}$ isotopic compositions are also similar to those of the subcontinental orogenic spinel lherzolites documented from the western Mediterranean region (Rampone et al., 1995). The fertile nature of these upper mantle peridotites is demonstrated by relatively high REE concentrations coupled with a moderate LREE/HREE depletion (Fig.3a), as well as high $\mathrm{Al}_{2} \mathrm{O}_{3}$ (Fig.3b) and $\mathrm{CaO}$ contents (Rampone et al., 1995). Several meters-thick garnet-bearing clinopyroxenite to websterite layers locally occur within the mantle sequences of the EL units (Montanini et al., 2006).

The upper mantle peridotites of the IL units consist of clinopyroxene-poor spinel lherzolites, which represent a rare example of the depleted mantle lithosphere of the Jurassic Ligurian Tethys (Rampone et al., 1998). These rocks exhibit severe depletion in highly incompatible elements, such as LREE (Fig. 3a), and less pronounced depletion in $\mathrm{Al}_{2} \mathrm{O}_{3}$ (Fig. 3b), $\mathrm{CaO}, \mathrm{Sc}$, and V. These geochemical features are consistent with those of a residual mantle, which
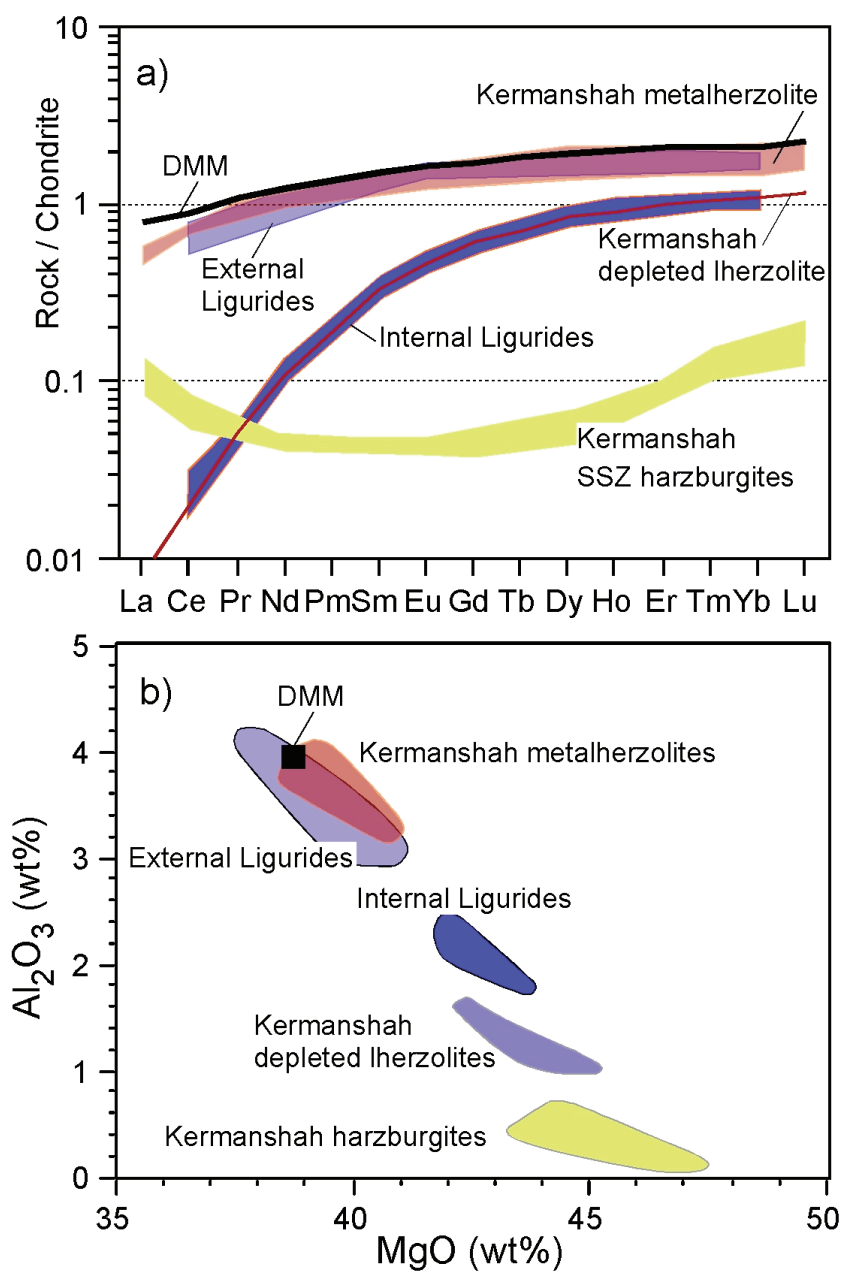

Figure 3. (a) Chondrite-normalized rare earth element (REE) compositional variation, and (b) variation of $\mathrm{Al}_{2} \mathrm{O}_{3}$ vs. $\mathrm{MgO}$ for mantle peridotites from the Western Tethys and Zagros ophiolites. The average composition of the depleted MORB mantle (DMM) is shown for comparison (data from Workmann and Hart, 2005). Normalizing values are from Sun and McDonough (1989). For data source, see Table 1, as well as Allahyari et al. (2010) for Kermanshah depleted lherzolites and harzburgites. 
underwent low-degrees $(<10 \%)$ of repeated episodes of partial melting, initiated in the garnet stability field (Rampone et al., 1998). The available $\mathrm{Sr}$ and $\mathrm{Nd}$ isotopic compositions of these peridotites indicate an extremely depleted signature, and the $\mathrm{Sm} / \mathrm{Nd}$ model ages suggest their partial melting experience during the Permian (Rampone et al., 1998). These observations and data suggest that the mantle rocks in the IL units represent the products of upwelling and melting of a MORB-type asthenosphere that formed in response to the onset of regional extensional tectonics, which led to the opening of the Western Tethys Ocean.

\section{Basaltic and metabasaltic rocks}

Although limited in volume, basaltic rocks are widespread in the Western Tethyan ophiolites. They mainly occur as blueschists and eclogites in the Western Alps, Alpine Corsica, and Calabria, and as unmetamorphosed basaltic lavas in the IL and EL units, as well as in some units in Alpine Corsica (Balagne, Nebbio, Pineto, Rio Magno). Two varieties of basaltic rocks are identified in the Western Tethyan ophiolites, regardless of their metamorphic grade: (1) basaltic rocks showing the typical geochemical features of N-MORB, and (2) NMORB lavas displaying marked garnet influence in the melt source; these basaltic rocks have been defined as G-MORB (garnet-influenced MORB) by Saccani (2015).

N-MORB rocks crop out in Alpine Corsica and the EL units of the Northern Apennines, and are represented mainly by basalts and minor basaltic andesites. These rocks show a clear sub-alkaline nature, as evidenced by their very low $\mathrm{Nb} / \mathrm{Y}$ ratios (0.04-0.09). Their $\mathrm{TiO}_{2}$ (0.98 - $1.78 \mathrm{wt} \%), \mathrm{P}_{2} \mathrm{O}_{5}(0.13-0.40 \mathrm{wt} \%), \mathrm{Zr}(53-192 \mathrm{ppm})$ and $\mathrm{Y}$ (20-48 ppm) contents, as well as Ti/V ratios (29-48), are highly similar to those of modern MORBs. The $\mathrm{Nb}$ and $\mathrm{Th}$ values plot along the MORB-OIB array and cluster towards relatively depleted compositions (Fig. 4a). These rocks show LREE depletion with respect to both MREE $\left(\mathrm{La}_{\mathrm{N}} / \mathrm{Sm}_{\mathrm{N}}=0.47-0.67\right)$ and $\operatorname{HREE}\left(\mathrm{La}_{\mathrm{N}} / \mathrm{Yb}_{\mathrm{N}}=0.53-\right.$ $0.91)$. In the discrimination diagram of Saccani (2015), these basaltic rocks plot in the typical N-MORB field (Fig. 4b).

Basaltic rocks with G-MORB affinities are volumetrically predominant in the Western Tethys ophiolites with respect to N-MORB (Table 1). These rocks generally show a wide range of fractionation degrees $(\mathrm{Mg} \#=81.7-50.5)$. Basaltic compositions are volumetrically predominant, whereas basaltic andesitic and ferrobasaltic rocks are subordinate. These basaltic rocks have overall chemical compositions that are highly similar to that of N-MORBs, as evidenced by their $\mathrm{TiO}_{2}(1.07-2.33 \mathrm{wt} \%), \mathrm{P}_{2} \mathrm{O}_{5}(0.10-0.44 \mathrm{wt} \%), \mathrm{Zr}(37-281 \mathrm{ppm})$ and $\mathrm{Y}(15-57 \mathrm{ppm})$ contents, as well as by their $\mathrm{Nb} / \mathrm{Y}(0.04-0.20)$ and Ti/V ratios (28-56). Although G-MORBs largely overlap with N-MORB compositions in Figure 4a, there is a tendency for GMORBs to plot towards compositions that are less depleted in Th and $\mathrm{Nb}$. Because of their comparatively higher contents in these elements as well as in their LREE/HREE ratios, some authors have interpreted these rocks as transitional-type MORBs (T-MORBs), generated from slightly enriched mantle sources during the onset of oceanic spreading (e.g., Venturelli et al., 1979). In their re-evaluation of this interpretation, Montanini et al. (2008) and Saccani et al. (2008a) have observed that these rocks typically show significant depletion in HREE with respect to MREE, and that their $(\mathrm{Dy} / \mathrm{Yb})_{\mathrm{N}}$ ratios $(1.15$ to 1.59 ; Fig. 4b) are higher than that of typical N-MORB $\left(\mathrm{Dy}_{\mathrm{N}} / \mathrm{Yb}_{\mathrm{N}}=\right.$ 1; Sun and McDonough, 1989). They have suggested, therefore, that the LREE/HREE enrichment was related to depletion in HREE rather
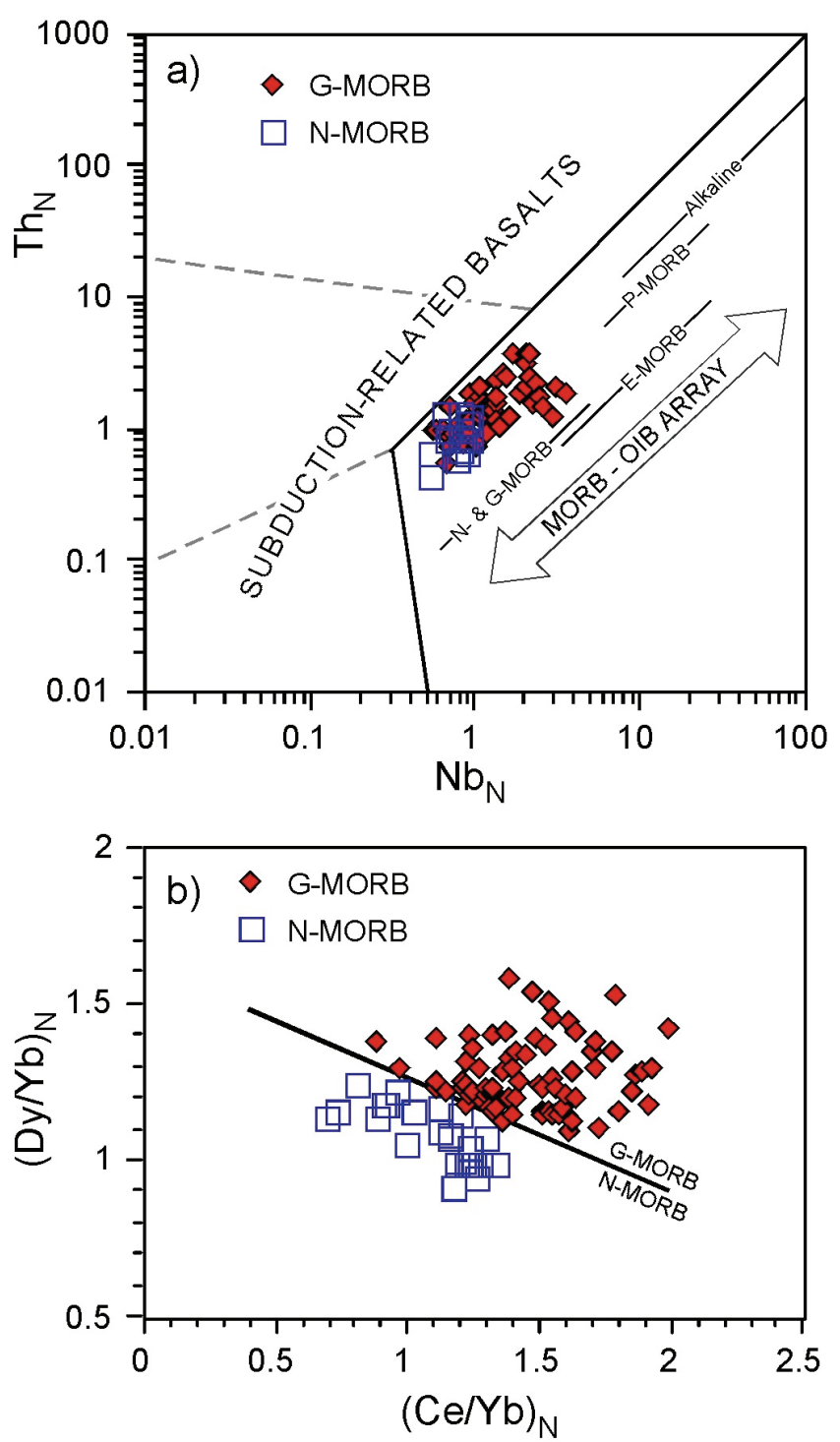

Figure 4. (a) $\mathrm{N}$-MORB-normalized $T h_{N} v s . N b_{N}$ diagram (Saccani, 2015) for basalts and metabasalts from the Western Tethys (Alps, Alpine Corsica, Apennine, and Calabria) ophiolites. Abbreviations, MORB: mid-ocean ridge basalt, $N$-: normal type, E-: enriched type, $P$-: plume type, G-: garnet-influenced type. Bars showing the compositional variation of $N-, E-, P-M O R B s$ and alkaline basalt from worldwide ophiolites are from Saccani (2015). (b) Chondritenormalized $(\mathrm{Dy} / \mathrm{Yb})_{N}$ vs. $(\mathrm{Ce} / \mathrm{Yb})_{N}$ diagram (Saccani, 2015) used for discriminating between G-MORB (garnet-influenced MORB) and N-MORB. Compared to N-MORBs, G-MORBs show a marked garnet signatures testified by HREE/MREE depletion (Saccani, 2015). Normalization values in both panels are from Sun and McDonough (1989). For data source, see Table 1.

than enrichment in LREE. They hence interpreted the HREE/MREE depletion as a clear garnet signature of their mantle sources.

\section{Mantle sources and petrogenesis of basaltic and metabasaltic rocks of the Western Tethys ophiolites}

Compositional variations observed in mafic rock suites commonly reflect the effects of fractional crystallization of olivine, plagioclase, and clinopyroxene in relatively evolved rocks (see Saccani et al., 
Table 1. Age, regional distribution, geochemical type, and related references of Jurassic and Triassic rocks in the key areas examined in this paper. ${ }^{(1)}$ : Age constrained on geological bases (see Saccani et al., 2008b for the W Vardar zone ophiolites and Saccani et al., 2013a for the Kermanshah ophiolites)

\begin{tabular}{|c|c|c|c|c|}
\hline Region & Unit & Age & Rock-type & References \\
\hline \multicolumn{5}{|c|}{ Western Tethys ophiolites } \\
\hline \multirow{3}{*}{ N. Apennine } & & & Mantle lherzolites & \\
\hline & External Liguride & & & Rampone et al., 1995 \\
\hline & Internal Liguride & & & Rampone et al., 1998 \\
\hline \multicolumn{5}{|c|}{ Basalts } \\
\hline W Alps & Platta & Jurassic & $\mathrm{G}$ & Desmurs et al., 2002 \\
\hline \multirow[t]{2}{*}{ Corsica } & Pineto, Rio Magno, Balagne & Jurassic & $\mathrm{G}, \mathrm{N}$ & Saccani et al., 2000; Saccani et al., 2008a \\
\hline & Schistes Lustres & Jurassic & $\mathrm{G}, \mathrm{N}$ & Saccani et al., 2008a \\
\hline \multirow[t]{2}{*}{ N Apennine } & External Ligurides & Jurassic & $\mathrm{G}, \mathrm{N}$ & Marroni et al., 1998; Vannucci et al., 1993 \\
\hline & Internal Ligurides & Jurassic & $\mathrm{G}$ & Cortesogno \& Gaggero, 1992; Rampone et al., 1998 \\
\hline Calabria & Pollino & Jurassic & $\mathrm{G}$ & E. Saccani's unpublished data \\
\hline \multicolumn{5}{|c|}{ Albanide-Hellenide ophiolites } \\
\hline \multicolumn{5}{|c|}{ Basalts } \\
\hline \multirow[t]{2}{*}{ Mirdita } & W \& E Belt mélanges & L-Triassic & $\mathrm{N}, \mathrm{E}$ & Bortolotti et al., 2004; Tashko et al., 2007 \\
\hline & Porava (S Mirdita) & M-L-Triassic & $\mathrm{N}, \mathrm{AB}$ & Bortolotti et al., 2006 \\
\hline \multirow[t]{12}{*}{ Hellenides } & Othrys mélange & M-L-Triassic & $\mathrm{N}, \mathrm{E}, \mathrm{P}, \mathrm{AB}, \mathrm{CAB}$ & $\begin{array}{l}\text { Photiades at al., 2003; Bortolotti et al., 2008; } \\
\text { Monjoie et al., 2008; Capedri et al., } 1997\end{array}$ \\
\hline & Koziakas mélange & M-L-Triassic & $\mathrm{N}, \mathrm{E}, \mathrm{P}, \mathrm{AB}$ & Capedri et al., 1997; Saccani et al., 2003a; Chiari et al., 2012 \\
\hline & Argolis mélange & Triassic $^{(1)}$ & $\mathrm{N}, \mathrm{E}, \mathrm{P}, \mathrm{AB}$ & $\begin{array}{l}\text { Capedri et al., 1997; Saccani et al., 2003b; } \\
\text { Saccani \& Photiades, } 2005\end{array}$ \\
\hline & W Vardar zone mélange & Triassic $^{(1)}$ & $\mathrm{N}, \mathrm{E}, \mathrm{AB}, \mathrm{CAB}$ & Saccani et al., $2008 b$ \\
\hline & Vardoussia mélange & M-L-Triassic & $\mathrm{N}, \mathrm{P}, \mathrm{CAB}$ & Capedri et al., 1997; Bortolotti et al., 2009 \\
\hline & Avdella mélange (Pindos) & L-Triassic & $\mathrm{N}, \mathrm{P}, \mathrm{AB}$ & Capedri et al., 1997; Jones \& Robertson, 1991 \\
\hline & Kerassies & L-Triassic & $\mathrm{E}, \mathrm{AB}$ & Pe-Piper, 1998 \\
\hline & Evvia \& Samos & E-M-Triassic & $\mathrm{AB}$ & Pe-Piper \& Panagos, 1989; Pe-Piper \& Kotopouli, 1991 \\
\hline & Atalanti & Triassic & $\mathrm{CAB}$ & Capedri et al., 1997 \\
\hline & Edipsos, Kremasta, Giona & M-Triassic & $\mathrm{CAB}$ & $\begin{array}{l}\text { Pe-Piper, 1983; Pe-Piper \& Panagos, 1989, } \\
\text { Pe-Piper \& Piper, } 1991\end{array}$ \\
\hline & Formation à blocs & L-Triassic & $\mathrm{CAB}$ & Pe-Piper, \& Mavroniki 1990 \\
\hline & Metalliko-Kilkis & E-Triassic & $\mathrm{CAB}$ & Asvesta, 1992 \\
\hline \multicolumn{5}{|c|}{ Zagros ophiolites } \\
\hline \multicolumn{5}{|c|}{ Metalherzolites } \\
\hline Zagros & Kermanshah & Pre-Jurassic ${ }^{(1)}$ & & Saccani et al., 2013a \\
\hline \multicolumn{5}{|c|}{ Metagabbros and metadykes } \\
\hline & Kermanshah & Pre-Jurassic ${ }^{(1)}$ & $\mathrm{G}, \mathrm{N}$ & Saccani et al., 2013a \\
\hline \multicolumn{5}{|c|}{ Basalts } \\
\hline & Kermanshah & Pre-Jurassic ${ }^{(1)}$ & $\mathrm{E}, \mathrm{P}, \mathrm{AB}$ & Ghazi Hassanipak, 1999; Saccani et al., 2013a \\
\hline & Sarve-Abad & Pre-Jurassic ${ }^{(1)}$ & $\mathrm{E}, \mathrm{P}$ & Saccani et al., 2014 \\
\hline
\end{tabular}

2008a). Most of the rocks examined in this study have Mg\# less than 70 , that is, lower than the $\mathrm{Mg} \#$ of $>70$ inferred for primary melts of MORB-type lherzolites (Sinton and Detrick, 1992). For this reason, our discussion on the petrogenesis of these rocks is based only on the most primitive samples. The petrogenesis of basalts and metabasalts in the Western Tethys ophiolites and the characteristic features of their mantle sources have been discussed extensively by Montanini et al. (2008) for the EL units, and by Saccani et al. (2008a) for the basalt and metabasalt occurrences in Alpine Corsica. We summarize the salient points and conclusions of these studies here, using the LREE/HREE vs. MREE/HREE ratios (Fig. 5) that are particularly useful for highlighting the garnet influence in mantle melt sources.
The main distinctive feature between N-MORBs and G-MORBs lies in different fractionation trends among LREE, MREE, and HREE that cannot be explained by fractional crystallization alone; however, it can be explained by variable influence of a garnet signature in their mantle sources (Montanini et al., 2008). The garnet signature can be related either to deep initiation of melting in the garnet peridotite stability field, or to the melting of a heterogeneous mantle source characterized by garnet-bearing mafic/ultramafic layers. The diagram in Figure 5 shows that primitive N-MORB compositions are compatible with $10-20 \%$ partial melting of a depleted MORB-type mantle (DMM) source in the spinel stability field. In contrast, the compositions of primitive G-MORBs are compatible with either partial melting of a DMM source bearing garnet pyroxenites, or partial 


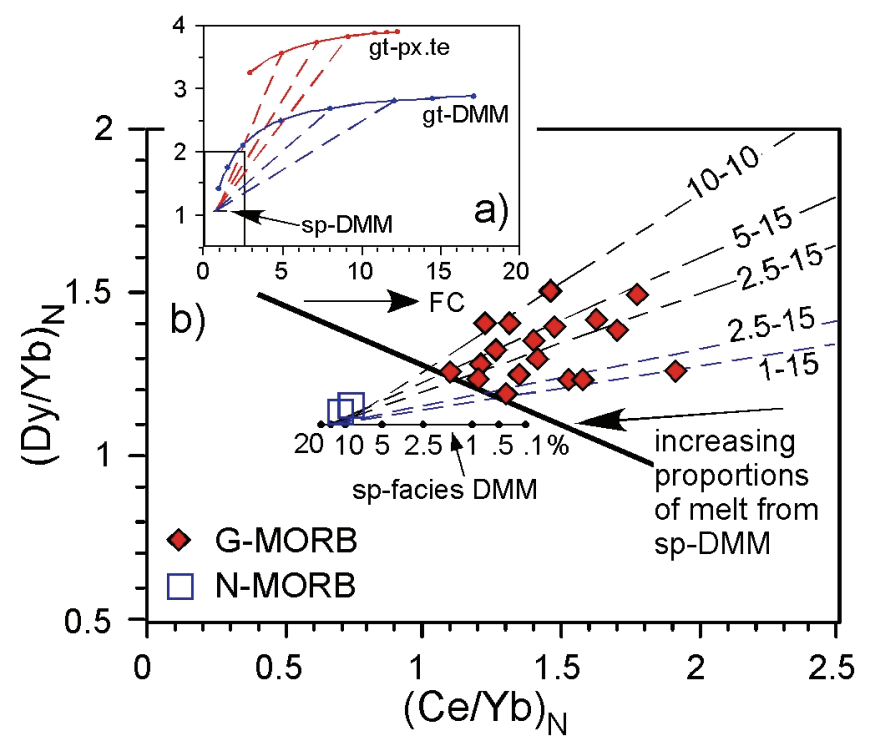

Figure 5. (a) Batch melting curves on $(\mathrm{Dy} / \mathrm{Yb})_{N}$ vs. $(\mathrm{Ce} / \mathrm{Yb})_{N}$ diagram for a garnet pyroxenite (gt-px.te) and a depleted MORB mantle (DMM) source in both garnet (gt) and spinel (sp) stability fields. Dashed lines represent the mixing lines of various melt fractions from different sources. DMM composition is from Workman and Hart (2005) garnet-pyroxenite composition is from Liu et al. (2005); Source modes, melting proportions, and partition coefficient are given in Appendix A. Box indicates the area expanded in panel (b). (b) Plot of the most primitive basalts and metabasalts from Western Tethys ophiolites on the close up of the melting model in panel (a). Red dashed lines represent the mixing lines of various melt fractions between DMM in the spinel stability field + garnet-pyroxenite relics; blue dashed lines represent mixing lines of various melt fractions between DMM in the spinel stability field +DMM in the garnet stability field. The percentages of melt fractions from each source are indicated on the mixing line (e.g., 5-15 indicates 5\% partial melt of sp-DMM that mix with $15 \%$ partial melt of gt-pyroxenite). Mixing proportions between different partial melts are not shown. However, samples plot in the range from $0.9-0.6$ melt from sp$D M M+0.1$ - 0.4 melt from other sources. Abbreviations, $N$-MORB: normal-type mid-ocean ridge basalt; G-MORB: garnet influenced MORB. See text for further explanations.

melting of a DMM source that started to melt in the garnet lherzolite field ( 1 $-2.5 \%$ melting) and that it continued to higher degrees ( $\sim 15 \%$ melting) in the spinel lherzolite field. All samples from the Western Tethys basalts and metabasalts fall within the mantle array (Fig. 4a), suggesting that a chemical influence of a lower crust component was limited or absent.

Basaltic lavas in the EL units of the Northern Apennines were likely the products of partial melting of a heterogeneous subcontinental lithospheric mantle bearing small volumes of garnet pyroxenite layers (Montanini et al., 2008). There exist several different interpretations for the inferred origin of garnet in the mantle melt source of these lavas. It might have been produced by relict garnetpyroxenite material left in the depleted mantle source after the delamination and sinking of parts of the deep garnet-pyroxenitebearing lithospheric mantle (Piccardo, 2008). Alternatively, it might have resulted from partial melting of a depleted MORB-type mantle source that initially started in the garnet-facies mantle and then continued in the spinel-facies mantle (Saccani et al., 2008a).

\section{Continental Margin Ophiolites in the Albanide-Hellenide Segment of the Alpine Orogen}

\section{Geology}

The NW-SE-trending Albanide-Hellenide mountain belt (Fig. 1) is part of the Alpine orogenic system and stretches from Slovenia and Serbia in the north to the mainland Greece in the south. Its late Mesozoic-Cenozoic tectonics was controlled mainly by the oblique convergence and continental collision between Adria and Europe, whereas its early Mesozoic tectonics was dominated by continental rifting, rift-drift tectonics and opening of an oceanic domain within the Neotethyan realm (e.g., Shallo and Dilek, 2003; Dilek et al., 2007, 2008; Bortolotti et al., 2013 and quoted references). Whether there was one or were two separate basins in this oceanic domain is still a subject of debate in the literature. Regardless of the paleogeography of the inferred ocean basin(s), final continental break-up and initial seafloor spreading in the Albanide-Hellenide segment of the Neotethyan system appear to have occurred in the Carnian-Norian (Bortolotti et al., 2013).

The main rift-drift events that lead to the opening of the Neotethys basin(s) in the region took place in the early-middle Triassic (Robertson et al., 1991). Upper Scythian and lower Anisian submarine lavas, locally associated with red limestones and cherts, are overlain by transgressive mid-Triassic limestones in the Tripolitsa, Subpelagonian and Pelagonian tectonic zones (Pe-Piper, 1998). Submarine volcanic rocks that are stratigraphically associated with late Anisian radiolarian cherts occur in the sub-ophiolitic mélanges in the Albanide-Hellenide belt (Jones et al., 1992, Chiari et al., 1996; Ozsvart et al., 2011). Rift-related volcanism appears to have continued into the late Triassic, as documented in numerous localities in the Albanide-Hellenide belt (see Table 1). Similar Triassic rift-related volcanic rocks intercalated with hemipelagic sedimentary rock sequences are widespread elsewhere in the Dolomite Alps of northern Italy (Winterer and Bosellini, 1981), in the Dinarides (Bébien et al., 1978, Pamiç, 1984), and in the Taurides of southern Turkey (Dilek and Rowland, 1993; Dilek et al., 1999).

\section{Geochemistry of Triassic mafic volcanic rocks}

Five main types of Triassic mafic to intermediate volcanic rock associations are distinguished in the Albanide-Hellenide belt (see Table 1 for localities and references): (1) calc-alkaline (CAB) and minor shoshonitic basalts, basaltic andesites and andesites; (2) alkaline basalts and subordinate trachybasalts, trachyandesites, and trachytes (e.g., Saccani et al., 2003a); (3) transitional to subalkaline basalts showing marked LREE/HREE enrichment, resembling plume-type MORB (P-MORB) compositions; (4) subalkaline basalts showing moderate LREE/HREE enrichment, resembling enriched-type MORB (E-MORB) compositions; and (5) sub-alkaline basalts showing N-MORB chemistry. We briefly summarize below the geochemical features of these main types of Triassic basaltic rock associations based on the existing literature (see Table 1 for regional distribution and references). Most of these volcanic rock associations are incorporated into sub-ophiolitic mélange units as discrete tectonic slices or blocks. However, only volcanic rocks that are spatially associated with Triassic sedimentary 
rocks (either carbonate rocks or radiolarian cherts) are described below.

\section{Calc-alkaline volcanic rocks}

Triassic calc-alkaline volcanic rocks are found in several extrusive units of the Hellenide belt, and rarely in the sub-ophiolitic mélanges of the Othris, Vardoussia, and Almopias ophiolites (Table 1). The calc-alkaline rocks in the Metalliko-Kilkis area are Lower Triassic in age (Asvesta, 1992), whereas all the other rock units are Middle to Upper Triassic in age. The main rock types include basalts, basaltic andesites, andesites, dacites and rhyolites, although basalts and basaltic andesites are more extensive by volume. Basaltic and andesitic rocks have low to moderate $\mathrm{TiO}_{2}(0.7-1.5 \mathrm{wt} \%), \mathrm{Zr}$ (64 - $\left.218 \mathrm{ppm}\right)$, and $\mathrm{Y}$ (16 - 47 ppm). They are sub-alkaline in nature (Fig. 6a), show significant Th enrichment with respect to $\mathrm{Nb}$ (Fig. 6b), and plot in the compositional field for calc-alkaline basaltic rocks. These rocks are characterized by incompatible element patterns with positive anomalies of Th, U, La, Ce and marked negative anomalies of Ta, Nb, Hf, and Ti (e.g., Pe-Piper and Piper, 1991; Capedri et al., 1997; PePiper, 1998; Bortolotti et al., 2009). They show highly variable LREE/ HREE enrichments, with $\mathrm{La}_{\mathrm{N}} / \mathrm{Yb}_{\mathrm{N}}$ ratios ranging from $\sim 2$ to $\sim 11$.

\section{Alkaline basaltic rocks}

Triassic alkaline rocks occur as hundreds of meters-thick successions in the volcanic sequences of the Porava unit in South Albania (Bortolotti et al., 2006), and on the islands of Evvia and Samos in Greece (Pe-Piper and Panagos, 1989; Pe-Piper and Kotopouli, 1991). They are also widespread in sub-ophiolitic mélanges of the Subpelagonian zone, where they are mainly represented by basalts, and subordinately by trachybasalts, trachyandesites, and trachytes (Capedri et al., 1997; Saccani et al., 2003a; Saccani and Photiades, 2005; Bortolotti et al., 2009). In the Vardar zone to the east, however, they are represented by metabasaltic rocks showing intense deformation (Saccani et al., 2008b). The alkaline nature of these rocks is marked by their $\mathrm{Nb} / \mathrm{Y}$ ratios $>1.4$ (Fig. 6a). Basaltic rocks have relatively high $\mathrm{TiO}_{2}(1.4-3.4 \mathrm{wt} \%)$ and $\mathrm{P}_{2} \mathrm{O}_{5}(0.2-1$ $\mathrm{wt} \%$ ) contents, and display significant enrichment in $\mathrm{Th}$ and $\mathrm{Nb}$ (Fig. $6 b)$, as well as marked LREE/HREE enrichments $\left(\mathrm{La}_{\mathrm{N}} / \mathrm{Yb}_{\mathrm{N}}=3.8-\right.$ 26.0). These elements and many incompatible element ratios (e.g., $\mathrm{Th} / \mathrm{Yb}=0.8-4.3 ; \mathrm{Ta} / \mathrm{Yb}=0.4-3.2)$ are highly similar to those observed in typical ocean island basalts (OIB) (Sun and McDonough, 1989), suggesting that magmas of these rocks in the Vardar Zone may have originated from an OIB-like mantle source. $\mathrm{Pb}$ and $\mathrm{Nd}$ isotope compositions of the Evvia and Samos alkali basalts resemble those of Saint Helena or Afar OIB, although their $\mathrm{Pb}$ isotopic compositions are similar to those of the Aegean granitoids suggesting a hint of crustal contamination (Pe-Piper, 1998). However, all transitional to alkaline basalts plot within the MORB - OIB array in Figure 6b, indicating that any possible chemical contamination from the lower crust should have been very limited.

\section{Highly enriched (plume-type) mid-ocean ridge basalts (P-MORBs)}

Middle to Late Triassic P-MORBs consisting of pillowed and massive lavas occur as thrust sheets within sub-ophiolitic mélanges beneath the Hellenide ophiolites (Table 1). These rocks are
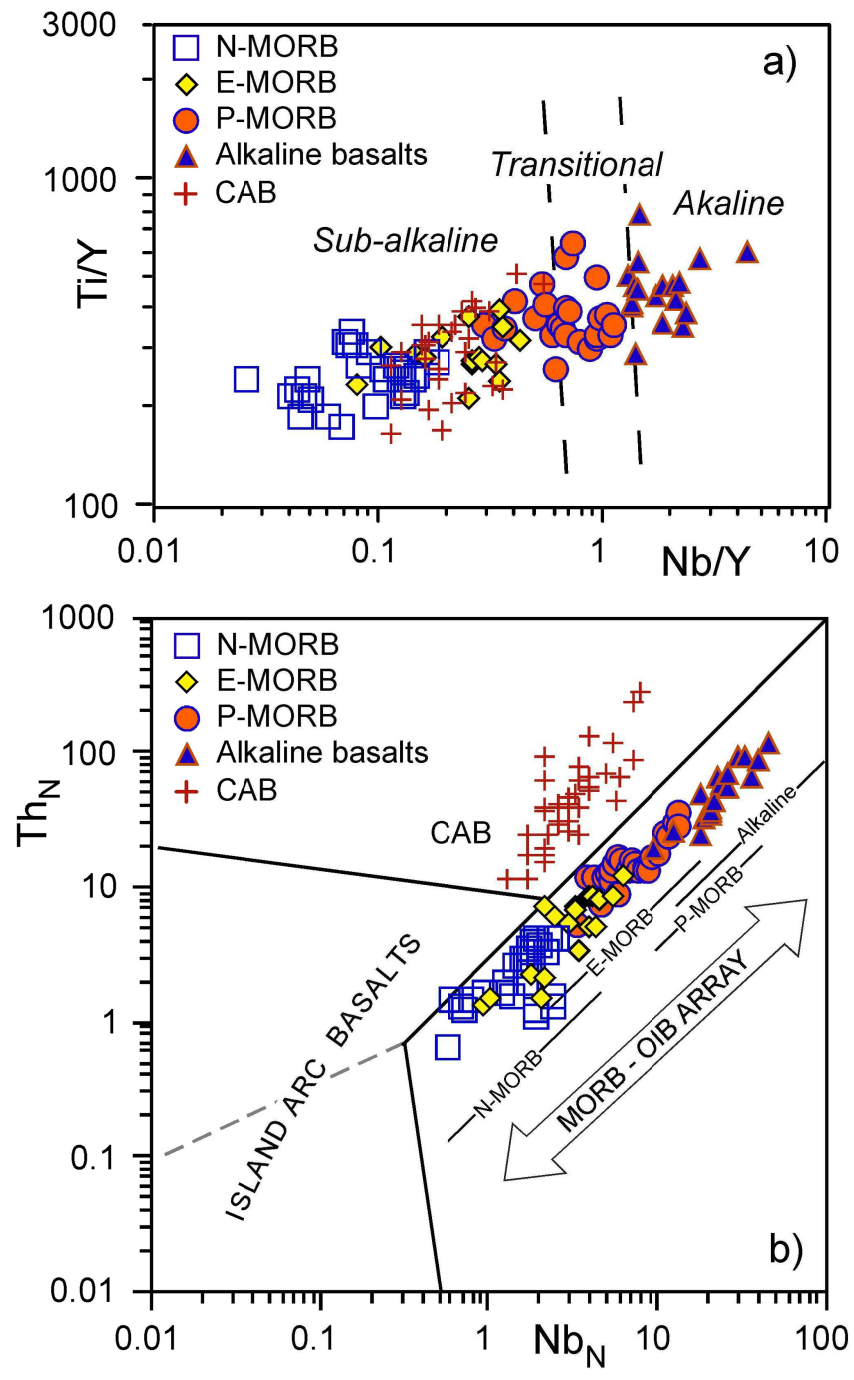

Figure 6. (a) Ti/Y vs. $\mathrm{Nb} / \mathrm{Y}$ diagram (Pearce, 1982), and (b) $\mathrm{N}$ MORB-normalized $\mathrm{Th}_{N} v \mathrm{~s} . \mathrm{Nb}_{N}$ diagram (Saccani, 2015) for Triassic basalts from the Albanide-Hellenide ophiolites. Abbreviations, MORB: mid-ocean ridge basalt, $N$-: normal type, E-: enriched type, $P$-: plume type, CAB: calc-alkaline basalt. Bars showing the compositional variation of $N$-, E-, P-MORBs and alkaline basalt from worldwide ophiolites are from Saccani (2015). Normalization values are from Sun and McDonough (1989). See Table 1 for data source.

characterized by rather variable chemical compositions and fractionation degrees $(\mathrm{Mg} \#=80-52)$. Their compositions range from basalt to ferrobasalt $\left(\mathrm{FeO}_{\mathrm{t}}=\sim 11-14 \mathrm{wt} \%\right)$, indicating that they are sub-alkaline to transitional in nature (Fig. 6a). They have $\mathrm{TiO}_{2}=0.83$ $2.28 \mathrm{wt} \%, \mathrm{P}_{2} \mathrm{O}_{5}=0.15-0.43 \mathrm{wt} \%, \mathrm{Zr}=45-196 \mathrm{ppm}$, and $\mathrm{Y}=13-40$ ppm, reminiscent of the geochemical features of plume-type MORBs (e.g., Schilling et al., 1983) generated at plume-proximal mid-ocean ridge settings. These basalts show marked enrichment in $\mathrm{Th}$ and $\mathrm{Nb}$ (Fig. 6b), as well as in Ta, Hf, and LREE. Their LREE abundance is generally lower than $100 \mathrm{x}$ chondrite (e.g., Saccani and Photiades, 2005) with $\mathrm{La}_{\mathrm{N}} / \mathrm{Yb}_{\mathrm{N}}=2.71-7.82$.

\section{Enriched mid-ocean ridge basalts (E-MORBs)}

Middle to Upper Triassic E-MORBs are widespread in the sub- 
ophiolitic mélanges of both the Mirdita-Subpelagonian and Vardar tectonic zones in the Albanide-Hellenide belt (Table 1). The E-MORB rocks consist of pillowed and massive lavas of basaltic and ferrobasaltic compositions, showing a clear sub-alkaline affinity (Fig. 6a). The E-MORBs examined in this study have rather variable chemical compositions and fractionation degrees $(\mathrm{Mg} \#=75-52)$. Their $\mathrm{TiO}_{2}$ (0.61-1.70 wt\%) values are generally lower than those in PMORBs, whereas their $\mathrm{P}_{2} \mathrm{O}_{5}(0.08-0.42 \mathrm{wt} \%), \mathrm{Zr}(30-125 \mathrm{ppm})$, and $\mathrm{Y}$ (14-42 ppm) contents are comparable to those of P-MORBs. The examined E-MORBs are characterized by a moderate $\mathrm{Th}$ and $\mathrm{Nb}$ (Fig. 6b) enrichment coupled with moderate LREE/HREE $\left(\mathrm{La}_{\mathrm{N}} /\right.$ $\left.\mathrm{Yb}_{\mathrm{N}}=1.4-3.3\right)$ and LREE/MREE $\left(\mathrm{La}_{\mathrm{N}} / \mathrm{Sm}_{\mathrm{N}}=1.0-1.7\right)$ enrichments. The overall geochemistry of these rocks is highly similar to that of modern E-MORBs (Sun and McDonough, 1989).

\section{Normal mid-ocean ridge basalts}

Middle to Upper Triassic rocks showing N-MORB chemistry are mainly found in sub-ophiolitic mélanges (Table 1). Nonetheless, they are also common in the Middle to Upper Triassic volcanic successions of the Porava unit (South Albania), where they are associated with alkaline basalts (Bortolotti et al., 2006). N-MORBs are represented by basalts, basaltic andesites, and ferrobasalts in the MirditaSubpelagonian zone, as well as by intensely deformed metabasalts in the sub-ophiolitic mélanges of the West Vardar zone (Saccani and Photiades, 2005; Saccani et al., 2008b).

N-MORBs display a clear sub-alkaline affinity (Fig. 6a) and are characterized by variable chemical compositions and fractionation degrees $(\mathrm{Mg} \#=70.0-52.0$ in basalts and basaltic andesites and 58.6 - 37.0 in ferrobasalts). However, their overall geochemical features are similar to those of basalts generated at mid-ocean ridges. They have $\mathrm{TiO}_{2}=0.75-2.43 \mathrm{wt} \%, \mathrm{P}_{2} \mathrm{O}_{5}=0.03-0.30 \mathrm{wt} \%, \mathrm{Zr}=45-125$ $\mathrm{ppm}$, and $\mathrm{Y}=21-49 \mathrm{ppm}$, and their $\mathrm{FeO}_{\mathrm{t}}$ contents ranges from 7.19 to $11.19 \mathrm{wt} \%$. They display little $\mathrm{Th}$, and $\mathrm{Nb}$ depletion or enrichment relative to other incompatible elements (e.g., Pe-Piper, 1998; Saccani and Photiades, 2005; Bortolotti et al., 2006, 2008). In Figure 6b their $\mathrm{Th}$ and $\mathrm{Nb}$ compositions plot within the typical N-MORB values (Saccani, 2015). Although they show a wide range of compositional variations, most of the samples cluster towards more enriched compositions and partly overlap with E-MORB samples. Basalts show variable depletions in LREE with respect to MREE and HREE, as evidenced by their $\mathrm{La}_{\mathrm{N}} / \mathrm{Sm}_{\mathrm{N}}(0.46-0.99)$ and $\mathrm{La}_{\mathrm{N}} / \mathrm{Yb}_{\mathrm{N}}(0.38-1.00)$ ratios, in line with their N-MORB affinity.

\section{Mantle sources and petrogenesis of basaltic rocks}

Calc-alkaline basalts $(\mathrm{CAB})$ display $\mathrm{Ta}, \mathrm{Nb}$, and $\mathrm{Ti}$ depletion, suggesting that their mantle source was already depleted as a result of previous melt extraction events (Pearce, 1982). The $\mathrm{Th} / \mathrm{Nb}$ relative enrichment (Fig. 6b) suggests that these mantle sources were significantly influenced by an arc-type geochemical component (Pearce, 1982; Saccani, 2015). CAB magmatism peaked in the middle late Triassic, and was spatially and temporally associated with rift-related igneous activity producing alkaline basalts and highly enriched to depleted MORBs in the absence of an active subduction (Pe-Piper, 1998). Isotopic data suggest that CABs formed under extensional conditions from partial melting of hydrated, melt-depleted peridotites in the sub-continental mantle along the northern margin of Gondwana (Pe-Piper, 1998). Depletion and further hydration of this mantle source probably took place earlier, during a Hercynian subduction event.

Several authors have suggested, based on isotopic and trace element data, that Triassic alkaline basalts of the Albanide-Hellenide ophiolites were derived from partial melting of a plume-type source; variably enriched, subalkaline and transitional MORB rocks were derived, on the other hand, from partial melting of MORB-type mantle sources, which were influenced by different OIB-type chemical contribution (e.g., Pe-Piper, 1998; Saccani and Photiades, 2005). Partial melting that generated enriched basalts may have occurred either in the deep (garnet-facies) or in the shallow (spinel-facies) mantle (Saccani and Photiades, 2005).

To constrain the nature of the mantle source and the depth of melting during the rift-drift phases is fundamental for better reconstructing the nature of geodynamic processes occurring during the initial phases of an oceanic basin evolution. However, a rigorous quantification of the melting processes is not possible because the composition of the mantle sources can only be postulated. Saccani and Photiades (2005) have shown that small variations in the hygromagmatophile element ratios within each rock group can be observed suggesting that magmas of different rocks within each group may have been derived from mantle sources that were slightly different in composition. However, a semi-quantitative modeling of the incompatible elements can place some constraints on the mode and nature of the mantle processes at a regional scale.

We present in Figure 7 a non-modal, batch partial melting model, using $\mathrm{Th}$ and $\mathrm{Nb} / \mathrm{Yb}$ ratio. This diagram has the advantage to combine two types of information in a single plot. The abundance of Th and $\mathrm{Nb}$ is used to evaluate the enrichment of the source, whereas the $\mathrm{Nb}$ / $\mathrm{Yb}$ ratio is sensitive to the presence of residual garnet in the source. In this Figure, four compositionally different mantle sources that undergo partial melting in both garnet- and spinel-facies are considered: (1) DMM source (Workman and Hart, 2005); (2) OIBtype source (Lustrino et al., 2002) with $\mathrm{Nb}=1.5 \mathrm{ppm}$, $\mathrm{Th}=0.18$ $\mathrm{ppm}, \mathrm{Yb}=0.353 \mathrm{ppm}$; (3) a theoretical, slightly enriched DMM source with $\mathrm{Nb}=0.63 \mathrm{ppm}$, $\mathrm{Th}=0.08 \mathrm{ppm}, \mathrm{Yb}=0.353 \mathrm{ppm}$; and (4) a theoretical, enriched DMM source with $\mathrm{Nb}=0.79 \mathrm{ppm}, \mathrm{Th}=0.10$ $\mathrm{ppm}, \mathrm{Yb}=0.353 \mathrm{ppm}$. The compositions of the sources 3 and 4 were assumed based on modeling, as recently presented by Saccani et al. (2013a, 2014).

Primitive alkaline basalts are compatible with low degree partial melting $(0.5-1 \%)$ of an OIB-type mantle source starting in the garnetfacies mantle and continuing to greater extent $(2.5-5 \%)$ in the spinelfacies (polybaric melting). Alternatively, the chemistry of these basalts can be explained by very low degree of melting $(<0.1 \%)$ of enriched DMM sources in the garnet facies (Fig. 7). However, such a very low degree of melting is unreasonable, and therefore this hypothesis is ruled out.

The chemistry of N-MORB rocks generally points to melt generation from a depleted MORB-type mantle at shallow levels. In fact, the $\mathrm{Th}-\mathrm{Nb}-\mathrm{Yb}$ composition of primary N-MORBs can be explained by variable degrees (generally, 8 - 20\%) of partial melting of a DMM source in the spinel facies (Fig. 7).

E-MORBs have Th and $\mathrm{Nb}$ compositions, which are slightly enriched compared to those of N-MORBs (Fig. 6b). Therefore, it can be postulated that E-MORBs represent melts derived from more enriched sources compared to N-MORBs. The modeling in Figure 7 shows that E-MORB compositions are compatible with variable degrees $(\sim 5-20 \%)$ of partial melting of a slightly enriched DMM 


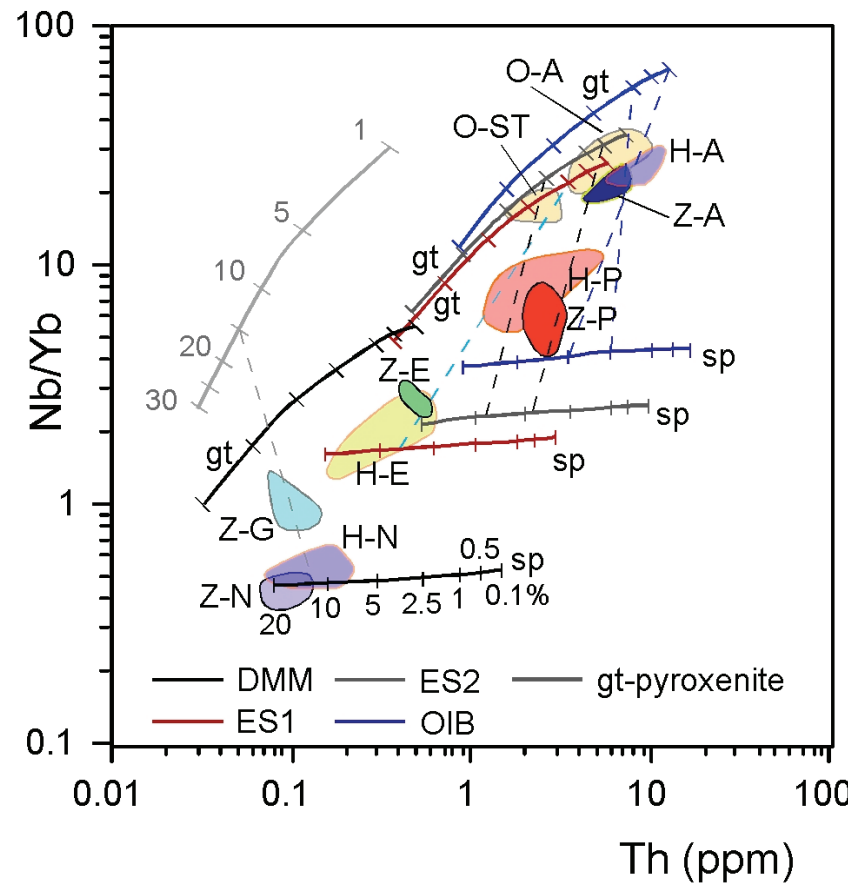

Figure 7. Plot of the Th vs. Nb/Yb compositional variations of the most primitive basalts from the Albanide-Hellenide and Zagros ophiolites, as well as batch melting curves for garnet-pyroxenite, depleted MORB mantle (DMM), and variably enriched theoretical mantle sources (ES1, ES2, OIB) in both garnet (gt) and spinel (sp) stability fields. ES1: slightly enriched source, ES2: moderately enriched source; OIB: ocean island basalt-type enriched source. Dashed lines represent the mixing lines of various melt fractions from different sources. DMM composition is from Workman and Hart (2005). Source modes, melting proportions, and partition coefficient are given in Appendix A. Ticks on the melting curves indicate the same percentages of melt fractions as shown for the sp-DMM. See text for further explanations. Abbreviations, $O$ : Oman; H: Albanide-Hellenide; Z: Zagros; A: alkaline; ST: subalkaline-transitional; P: plume-type mid-ocean ridge (MOR); E: enriched-type MOR; N: normal-type MOR; G: garnet-influenced MOR.

source (ES1) in the spinel facies. Alternatively, E-MORBs may have been derived from polybaric melting of a DMM source, starting in the garnet facies. However, the REE compositions of these rocks (not shown) cannot be explained by this melting process alone.

$\mathrm{P}-\mathrm{MORB}$ s have $\mathrm{Th}$ and $\mathrm{Nb}$ contents that plot toward the enriched values within the MORB-OIB array (Fig. 6b). Although definitely enriched in many incompatible elements, the overall chemical composition of these rocks points to a MORB-type composition. Therefore, we can rule out the possibility of their genesis from an OIB-type source. However, it can be postulated that these rocks represent melts derived from more enriched sources compared to $\mathrm{N}$ MORBs and E-MORBs. The diagram in Figure 7 shows that the Th$\mathrm{Nb}-\mathrm{Yb}$ composition of primitive $\mathrm{P}-\mathrm{MORB}$ is compatible with polybaric melting of the theoretical enriched source (ES2) starting in the garnet-facies $(0.5-2.5 \%$ melt $)$ and continuing into the spinel facies ( $5-10 \%$ melt). Alternatively, primitive P-MORBs may have been derived from polybaric melting of a slightly enriched source (ES1). However, this hypothesis would require implausible melting proportions, that is: very low degree of melting in the garnet-facies
$(<0.5 \%)$, followed by a much greater extent of melting in the spinelfacies (e $\geq 20 \%$ ). In addition, the difference between hygromagmatophile element ratios of E-MORBs and P-MORBs (not shown) suggests that they were derived from compositionally distinct mantle sources.

\section{Continental margin ophiolites in the Zagros Belt}

\section{Regional Geology}

The Zagros ophiolites crop out along the Main Zagros Thrust Zone (MZTZ) in western Iran and display a complete record of the rift-drift, seafloor spreading and subduction zone tectonic evolution of the Southern Neotethyan Ocean. The Southern Neotethyan seaway opened in the Iranian-Oman segment during the Early-Middle Triassic (Agard et al., 2005; Robertson, 2007) and evolved between Arabia and the Sanandaj-Sirjan continental block (Berberian and King, 1981; Alavi, 1994; Agard et al., 2005; Mouthereau et al., 2012). The MZTZ ophiolites include, from NW to SE, the Penjween ophiolites in Iraq (Aswad et al., 2011) and the Sarve-Abad, Kermanshah, Neyriz, and Baft ophiolites in Iran (Ghazi and Hassanipak, 1999; Babaie et al., 2006; Allahyari et al., 2010, 2014; Rajabzadeh and Dehkordi, 2013; Shafaii Moghadam et al., 2013; Saccani et al., 2013a, 2014). They are temporally equivalent to the Oman ophiolite in the south (Glennie, 2000).

From the southwest to the northeast and structurally upward, three main tectonic units occur along the MZTZ: (1) the Zagros Fold Belt, (2) the Zagros Crush zone (or High Zagros) with ophiolites, and (3) the Sanandaj-Sirjan zone (SSZ). The Zagros fold belt consists mainly of Triassic to Upper Cretaceous shelf carbonates overlain by a Paleocene to Pliocene sedimentary succession. These shelf deposits have been interpreted to represent the Arabian passive margin (Stöcklin, 1968).

The Sanandaj-Sirjan zone consists of metamorphic and sedimentary sequences (Stöcklin, 1968; Berberian and King, 1981) that are composed of a Precambrian-Paleozoic continental basement, unconformably overlain by Permian-Triassic limestones, Jurassic phyllites with metavolcanic rocks, and Barremian-Aptian limestones (Stöcklin, 1968). The Jurassic sequence is intruded by late Jurassiclate Cretaceous calc-alkaline plutons. From the Middle Jurassic to the Cretaceous, the Sanandaj-Sirjan zone represented an Andean-type margin with robust calc-alkaline magmatism (e.g., Stöcklin, 1968; Berberian and King, 1981; Ghasemi and Talbot, 2006).

The Zagros Crush zone is composed of imbricated tectonic slices including: (1) Upper Triassic-Cretaceous limestones (Bisotun unit) and radiolarites deposited on the subsiding peri-Arabian shelf (see Stöcklin, 1968 for a detailed review); (2) ophiolitic units, (3) Upper Cretaceous sedimentary rocks and calc-alkaline andesitic lavas, and (4) Eocene-Miocene sedimentary deposits and volcanic rocks. Although Sabzehei and others (1968) described the Upper Cretaceous sedimentary-volcanic sequences as part of the Crush zone, it is likely that these units belong to the Andean-type volcanic arc that developed on the southern margin of the Sanandaj-Sirjan continental block (Berberian and King, 1981) because they show a clear calc-alkaline affinity.

Ophiolitic remnants commonly occur in a tectonic mélange (Stöcklin, 1968), which includes ophiolitic subunits as isolated and 
dismembered blocks. These ophiolitic subunits are represented by: (1) upper mantle peridotites; (2) ultramafic cumulates, (3) gabbroic sequences; (4) dike rocks; and (4) pillow basalts. Also included in this melange are metamorphosed lherzolites and gabbros that are intruded by numerous basaltic dikes.

Upper mantle peridotites are volumetrically the most abundant ophiolitic subunit, and are represented mainly by harzburgites and subordinate depleted lherzolites, locally intruded by pyroxenite dikes and dunite-chromitite bands (Allahyari et al., 2010; Rajabzadeh and Dehkordi, 2013; Shafaii Moghadam et al., 2013). Ultramafic cumulates have been described from the NW part of the Zagros Belt, namely in the Penjween area (Aswad et al., 2011) and in the SarveAbad ophiolites (Allahyari et al., 2014). These upper mantle peridotites and ultramafic cumulates are interpreted as the mantle residua and the cumulate sequence, respectively (Allahyari et al., 2010, 2014; Aswad et al., 2011; Rajabzadeh and Dehkordi, 2013; Shafaii Moghadam et al., 2013). Gabbros crop out in the Sarve-Abad, Kermanshah, Neyriz and Baft ophiolites, and are locally associated with troctolites and/or diorites and plagiogranites, as well as basaltic dikes and pillow lavas (Ghazi and Hassanipak, 1999; Babaie et al., 2006; Allahyari et al., 2010, 2014; Rajabzadeh and Dehkordi, 2013; Saccani et al., 2013a, 2014; Shafaii Moghadam et al., 2013). Gabbros and basalts mainly occur as isolated blocks in the Kermanshah, Neyriz and Baft areas, whereas an incomplete ophiolite sequence of cumulate and isotropic gabbros, microgabbros, a dike complex, a dike/pillow transition zone and pillow lavas exist in the Sarve-Abad area. Gabbroic and volcanic rocks from the MZTZ ophiolites display a wide range of geochemical affinities, ranging from E-MORB to P-MORB, and alkaline basalts and trachytes (Ghazi and Hassanipak, 1999; Babaie et al., 2006; Allahyari et al., 2010, 2014; Rajabzadeh and Dehkordi, 2013; Saccani et al., 2013a, 2014; Shafaii Moghadam et al., 2013).

Metamorphosed ophiolites have so far been described only from the Kermanshah area, where they mainly consist of foliated metagabbros crosscut by numerous metabasaltic dikes. Strongly serpentinized and foliated meta-peridotites occur below these metagabbros and consist of sub-continental meta-lherzolites, analogous to those exposed in the EL units of the Northern Apennines (Saccani et al., 2013a). Metagabbros and the associated mafic dikes have a general N-MORB affinity, but two sub-groups of rocks are also recognized: (1) rocks showing no garnet influence, and (2) rocks showing a marked garnet influence (Saccani et al., 2013a).

The Zagros ophiolites were emplaced onto the Arabian continental margin in the Campanian-Maastrichtian as a result of an arc-continent collision (Desmons and Beccaluva, 1983; Ricou, 1994; Agard et al., 2005; Dilek and Sandvol, 2009; Aswad et al., 2011; Saccani et al., 2013a). Andean-type, active margin magmatism continued along the southern edge of the Sanandaj-Sirjan block between the late Cretaceous and the Eocene, and produced calc-alkaline volcanic and plutonic rocks (Berberian and King, 1981; Agard et al., 2005; Ghasemi and Talbot, 2006). The collision of Arabia with Eurasia in the middle Miocene caused thrusting of the Eocene magmatic rocks over the ophiolite complexes.

\section{Geochemistry}

\section{Metalherzolites, metagabbros and metabasaltic dikes}

Metalherzolites of the Kermanshah ophiolite can readily be distinguished from the lherzolites representing MORB residual mantle and harzburgites, representing SSZ residual mantle in other MZTZ ophiolites (e.g., Penjween: Aswad et al., 2011; Neyriz: Babaie et al., 2006; Rajabzadeh and Dehkordi, 2013; Baft: Shafaii Moghadam et al., 2013). The Zagros metalherzolites have higher HFSE (high field strength elements) and REE concentrations (Fig. 3a) compared to the other upper mantle peridotites (Saccani et al., 2013a). Their REE values (Fig. 3a) and $\mathrm{TiO}_{2}, \mathrm{Al}_{2} \mathrm{O}_{3}$ (Fig. 3b), $\mathrm{CaO}, \mathrm{MgO}, \mathrm{Ni}$, and $\mathrm{Cr}$ contents are highly similar to those of the sub-continental lherzolites in the EL units of the Northern Apennines (Saccani et al., 2013a). Hence, we have interpreted these Zagros metalherzolites to represent the sub-continental mantle of the Arabian margin (Saccani et al., 2013a).

Magmatic protoliths of the metagabbros were composed of olivine-gabbros and both cumulate and isotropic gabbros, whereas those of dike intrusions in the metagabbros were made of basalts (Saccani et al., 2013a). Both isotropic metagabbros and metabasaltic dikes have relatively high contents of $\mathrm{TiO}_{2}, \mathrm{Zr}, \mathrm{Y}$, and $\mathrm{V}$, and relatively low $\mathrm{Al}_{2} \mathrm{O}_{3}$. These rocks are subalkaline in nature (Fig. 8a), and plot along the MORB-OIB array towards relatively depleted compositions in the discrimination diagrams (Fig. 8b). They can be subdivided, however, into distinct, N-MORB and G-MORB groups on this discrimination diagram (Fig. 8b).

The Zagros N-MORB rocks include some of the metabasaltic dikes, which display smooth MREE/HREE enrichments $\left(\mathrm{Dy}_{\mathrm{N}} / \mathrm{Yb}_{\mathrm{N}}=\right.$ 1.07 to 1.11) and marked LREE/MREE depletion $\left(\mathrm{Ce}_{\mathrm{N}} / \mathrm{Dy}_{\mathrm{N}}=0.68-\right.$ $0.87)$. In contrast, G-MORB rocks include metagabbros and some metabasaltic dikes. These G-MORB rocks display flat N-MORB normalized HFSE patterns, and chondrite-normalized REE compositions showing LREE/MREE depletion $\left(\mathrm{Ce}_{\mathrm{N}} / \mathrm{Dy}_{\mathrm{N}}=0.77-\right.$ 1.22), coupled with marked MREE/HREE enrichment $\left(\mathrm{Dy}_{\mathrm{N}} / \mathrm{Yb}_{\mathrm{N}}=\right.$ 1.31 - 1.44) (Saccani et al., 2013a). Such MREE/HREE enrichment is significantly higher than that of typical N-MORB (e.g., Dy $/$ $\mathrm{Yb}_{\mathrm{N}}=0.99$, Sun and McDonough, 1989). These values are comparable to those of equivalent basalts from the EL units in the Northern Apennines.

\section{Volcanic rocks}

The Zagros E-MORBs are represented by basalts and basaltic andesites showing a sub-alkaline nature (Fig. 8a). These rocks are characterized by slightly enriched LILE/HFSE and LREE/HREE patterns. They also have a generally lower concentration of incompatible elements with respect to those of P-MORBs and alkaline rocks (e.g., Saccani et al., 2013a).

P-MORBs in the Zagros ophiolites are represented by basalts, basaltic andesites and rare andesites that generally have a sub-alkaline to transitional nature (Fig. 8a) These rocks display multi-element patterns significantly enriched in LILE and LREE compared to HFSE and HREE, respectively, with $(\mathrm{La} / \mathrm{Yb})_{\mathrm{N}}$ ratios ranging from 2.46 to 4.37 (see Ghazi and Hassanipak, 1999; Saccani et al., 2013a, 2014). These patterns are similar to those of typical P-MORB from modern oceanic settings (e.g., Schilling et al., 1983).

Alkaline rocks in the Zagros are represented mainly by basalts and subordinately by trachybasalts and trachytes, displaying a clear alkaline nature (Fig. 8a). Alkaline basalts show high abundance in HFSE with respect to N-MORB and display LREE/MREE and LREE/ HREE enriched patterns (see Ghazi and Hassanipak, 1999; Saccani et al., 2013a, 2014). In the discrimination diagram in Figure 8b, these 

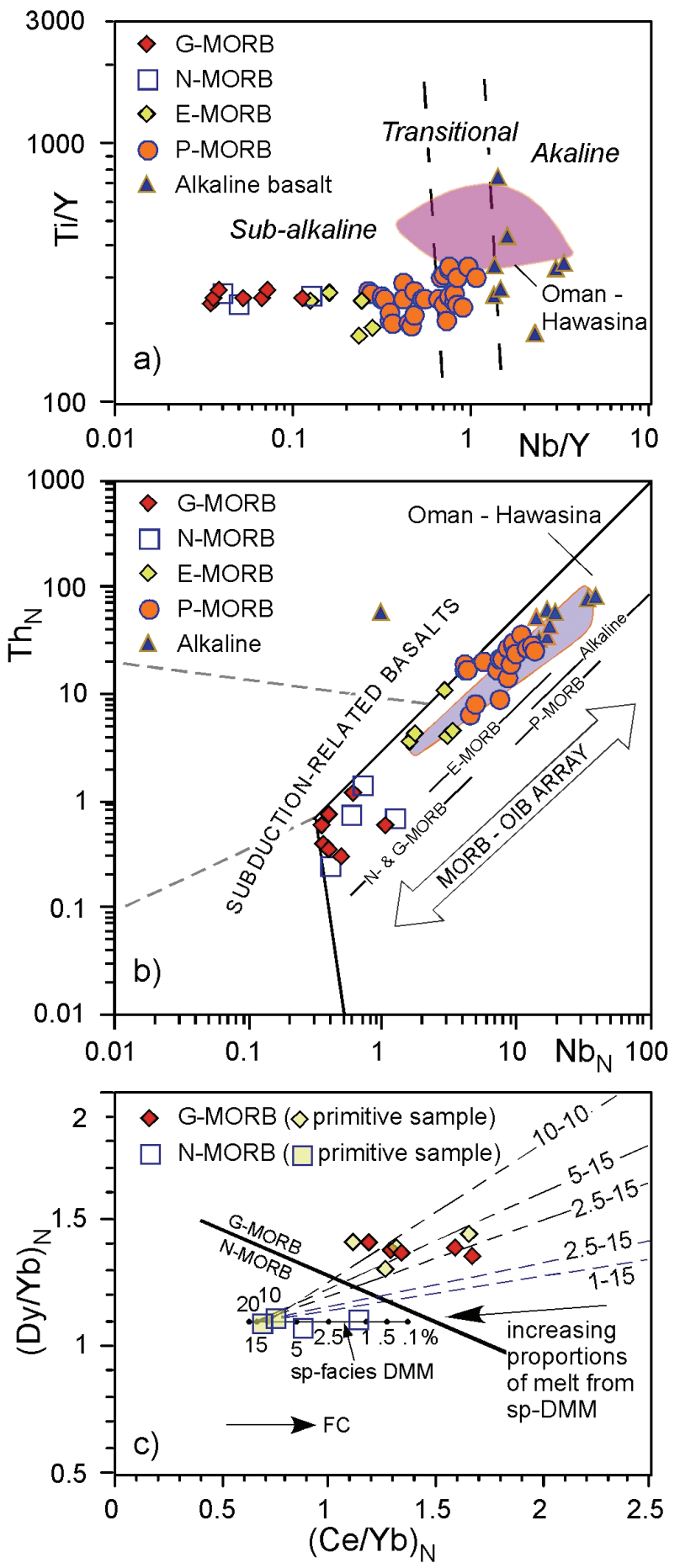

Figure 8. (a) Ti/Y vs. Nb/Y diagram (Pearce, 1982), and (b) $\mathrm{N}$ MORB-normalized $T h_{N} v s . N b_{N}$ diagram (Saccani, 2015) for basalts and metabasalts from the Zagros ophiolites. Abbreviations, MORB: mid-ocean ridge basalt, $N$-: normal type, E-: enriched type, $P-$ : plume type, G-: garnet-influenced type. Bars showing the compositional variation of $N-, G-, E-, P$-MORBs and alkaline basalt from worldwide ophiolites are from Saccani (2015). The compositional variation of basalts from the Hawasina Nappe from Oman ophiolites (Chauvet et al., 2011) is shown for comparison. (c) Chondrite-normalized $(\mathrm{Dy} / \mathrm{Yb})_{N}$ vs. $(\mathrm{Ce} / \mathrm{Yb})_{N}$ diagram (Saccani, 2015) used for discriminating between G-MORB and N-MORB. Normalization values in both panels $(b)$ and (c) are from Sun and McDonough (1989). See Table 1 for data source. volcanic units from the MZTZ ophiolites show a continuous compositional variation from the less enriched to the more enriched rocks. Their overall geochemistry resembles that of alkaline basalts generated in within-plate ocean island settings (OIB-type).

\section{Mantle sources and petrogenesis of basaltic rocks}

Our modeling in Figure 7 shows that N-MORB primitive metabasalts may have been derived from $~ 15-20 \%$ non-modal batch partial melting of a DMM source (Workman and Hart, 2005) in the spinel-facies. In contrast, the LREE/HREE (Ce/Yb) and MREE/HREE (Dy/Yb) ratios of G-MORB metagabbros and primitive metabasalts are compatible with $\sim 10-15 \%$ partial melting of DMM with garnetpyroxenite layers in the spinel-facies (Figs. 7 and 8c). Based on these figures we can exclude a possible genesis of G-MORBs from polybaric melting of a DMM source starting in the garnet-facies and then continuing into larger degrees of partial melting in the spinel-facies. Such melting process would result in comparatively lower MREE/ HREE ratios. Alternatively, the LREE/HREE and MREE/HREE ratios of G-MORB could theoretically be generated by large degree (10$15 \%$ ) of partial melting of a DMM source in the garnet-facies, followed by a lower extent of melting in the spinel facies (Fig. 7). However, this scenario is also implausible.

Many geochemical indicators (basically, highly incompatible and hygromagmatophile elements) suggest that the E-MORBs, P-MORBs, and alkaline basalts in the Sarve-Abad and Kermanshah ophiolites were originated from chemically distinct mantle sources, which started melting at different depths (see Saccani et al., 2013a, 2014). Primary E-MORBs are compatible with $\sim 10 \%$ partial melting of a DMM source slightly enriched in LREE and incompatible elements (e.g., $\mathrm{Th}, \mathrm{Nb}$, and $\mathrm{Ta}$ ), whereas the primary P-MORB may result from $\sim 8 \%$ partial melting of a DMM source, significantly enriched in LREE and incompatible elements (Saccani et al., 2013a, 2014). Both these rock-types were generated from partial melting in the spinel-facies mantle. However, a very limited contribution from the garnet-facies mantle cannot be excluded. In contrast, the REE systematics displayed by the alkaline basalts suggests that primary melts of these rocks were produced by the mixing of small melt fractions $(\sim 1 \%)$ from garnet-facies with larger melt fractions $(\sim 4 \%)$ from spinel-facies, derived from partial melting of an OIB-type lherzolite mantle. The results of our modeling, using Th vs. $\mathrm{Nb} / \mathrm{Yb}$ in Figure 7, are consistent with these conclusions. We can see in this figure that mantle sources that are progressively enriched in $\mathrm{Th}$ and $\mathrm{Nb}$ are required to explain the compositional variations observed from E-MORBs to P-MORBs and alkaline basalts in the Zagros ophiolites. It is worth noting that the oldest melts in the production of the Middle to Late Triassic basaltic rocks in the conjugate Oman margin show isotopic evidence for lower crustal contamination.

\section{Discussion}

\section{Tectono-magmatic model for the rift-drift evolution of the Alpine Tethys}

The rifting model proposed for the Western Tethys oceanic basin is mainly based on the reconstruction of the architecture of a deformed and metamorphosed continental margin pair, currently exposed in the Northern Apennines and Alpine Corsica. The first rifting stage started in the Middle Triassic (Fig. 9a) and was preceded by a long- 
lived extensional deformation episode in the Permo-Triassic that involved the transition from a gravitational collapse of the Variscan orogenic crust to the inception of a true rift-drift phase. In the Northern Apennines, evidence for this rifting phase can be found at Punta Bianca, where a middle Triassic extensional basin sequence consisting of marine deposits intercalated with alkaline basaltic flows crops out (Stoppa, 1985). Rifting-related middle Triassic faults also occur in the continental domain of Alpine Corsica and in the Western Alps (Durand-Delga; 1984; Froitzheim and Manatschal, 1996). The geometry of these normal faults, which are west-facing in the Southalpine and Austroalpine domains (Bernoulli et al., 1979; Bertotti et al., 1993) and east-facing in the Briançonnais and Dauphinois domains (Lemoine and Trumpy, 1987), suggests that this first rifting phase was dominated by lithospheric-scale stretching by pure shear extension (Fig. 9a)

The second stage of rifting (Fig. 9b) via an asymmetric, simpleshear kinematics developed in the Middle Jurassic (e.g., Marroni et al., 1998). However, the main episode of normal faulting associated with dismemberment of the carbonate platforms took place in the early Jurassic, as documented from the Adria continental margin sequences in the Northern Apennines (Bernoulli et al., 1979), Alpine Corsica (Durand-Delga, 1984) and Western Alps (Bertotti et al., 1993). The asymmetric crustal architecture of these continental margins can be deduced from the structure of the Corsica - Northern Apennine conjugate margin pair.

Reconstruction of the OCTZ at the European margin indicates the existence of upper continental crustal rocks, displaying prominent topographic escarpments produced by high-angle normal faults (Fig. 9b1). Slide blocks in the late Cretaceous sedimentary mélanges (e.g., Casanova Complex; Marroni et al., 1998) of the EL units show, on the other hand, that the Adria rifted margin was characterized by a wide OCTZ with subcontinental lithospheric mantle and lower continental crust exhumed on the seafloor, and tectonically overlain by extensional allochthons (or extensional rafts) (Fig. 9b1). Adria represented the lower plate in this asymmetric extension scenario, whereas Europe marked the upper plate (Marroni and Pandolfi, 2007 and quoted references). The middle to late Jurassic oceanic crust formation was characterized by a magma-poor, slow-spreading midocean ridge system. The more internal oceanic areas experienced limited volcanism, which took place directly on the exhumed, serpentinized mantle peridotites, gabbros, and/or ophiolitic breccias, as deduced from the IL units and the Schistes Lustrés units (Fig. 9b3). The middle to late Jurassic rift-drift stage was associated with upwelling of asthenospheric mantle in response to lithospheric extension and continental rifting. This extensional phase was associated with limited partial melting of heterogeneous mantle

a) Middle Triassic
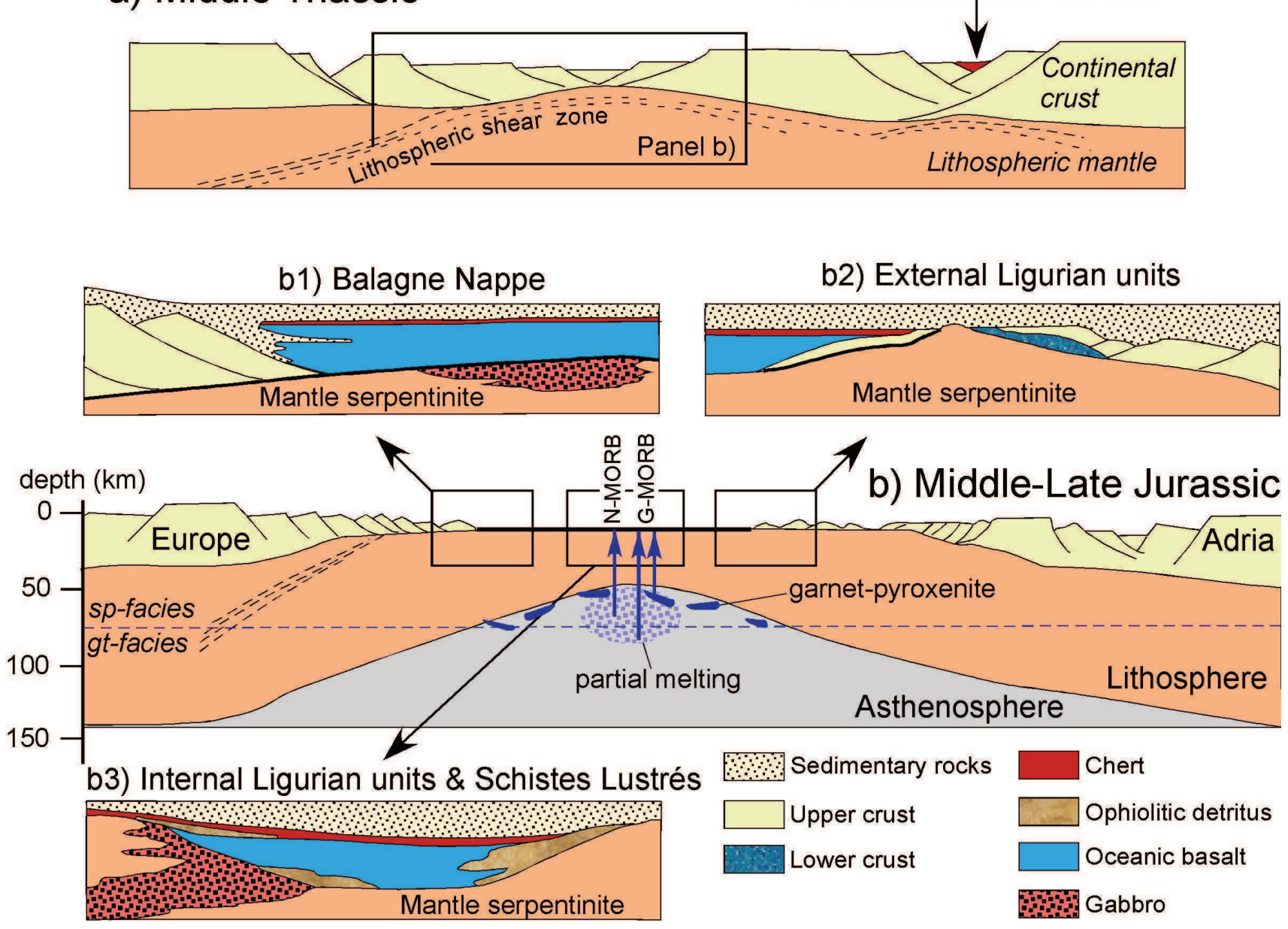

Figure 9. 2-D cartoons showing the rift-drift, tectono-magmatic evolution of the Western Tethys ocean basin (modified from Marroni and Pandolfi, 2007). Generalized stratigraphic and magmatic settings in different sections of the Western Tethys are also shown. (b1) European margin ocean-continent transition zone (OCTZ); (b2) Adria margin OCTZ; (b3) internal oceanic area. 
sources, locally bearing garnet-pyroxenite relics (Fig.9b). Piccardo (2008) suggested that garnet-pyroxenite relics were left in the DMM melting source after the delamination and sinking of portions of the deep garnet-pyroxenite-bearing lithospheric mantle. This partial melting process resulted in the formation of G-MORB type rocks now exposed in the Western Tethyan ophiolites. However, a minor amount of G-MORBs may have been generated from polybaric partial melting, which started in the garnet lherzolite field and continued to higher degrees in the spinel lherzolite field. The model in Figure $9 \mathrm{~b}$ can also explain the occurrence of volumetrically minor basalts with typical N-MORB compositions in several ophiolitic units in Alpine Corsica (Saccani et al., 2008a), as well as in the Ligurian ophiolites (Rampone et al., 2005). N-MORB primary melts could also be produced by partial melting of a pure DMM source, which did not contain garnet-bearing rocks.

\section{Tectono-magmatic model for the rift-drift evolution of the Albanide-Hellenide belt}

The Triassic rift-drift phase in the Albanide-Hellenide segment of Neotethys involved the formation of alkaline and variably enriched rocks with plume-like chemical signatures, and with calc-alkaline and shoshonitic rocks displaying SSZ-type chemical features. However, the extant geological evidence suggests that the Triassic extension and the early phase of oceanic crust formation at the OCTZ within the Albanide-Hellenide segment of Neotethys were not associated with a major mantle plume event or a contemporaneous active subduction (Pe-Piper, 1998). There is no physical evidence, such as regional doming, anomalous thermal regime, and basaltic plateaus, supporting the existence of a mantle plume in this area. In contrast, Wooler et al. (1992) have suggested that subsidence rates were small, and that there was hardly any uplift, with the rift shoulders remaining near the sea-level. The lack of magmatic evolution from more depleted to more enriched rocks that is commonly observed in plume-related magmatism, the absence of basaltic plateaus, and a relatively small volume of plume-related volcanic rocks collectively argue against the existence of a well established, long-lasting mantle plume in the region.

Calc-alkaline and shoshonitic rocks were produced, contemporaneously with the formation of alkaline basalts, between the early and late Triassic in both continental (e.g., Kremasta, Evia) and oceanic settings (e.g., Edipsos, Othrys mélange, and west Vardar zone mélange (see Table 1 for references). Magmas of these calcalkaline rocks may have been produced by partial melting of hydrated, melt-depleted peridotite in the sub-continental mantle. Pe-Piper (1998) has suggested that a previous, Hercynian subduction event that produced an Andean-type arc on the northeastern margin of Gondwana may have played an important role in hydrating the subcontinental lithospheric mantle. Subsequent partial melting of this previously metasomatized lithospheric mantle during the Triassic extension and rifting episode would have then produced calc-alkaline and shoshonitic melts. The occurrence of similar extensional, Triassic calcalkaline and shoshonitic rocks with similar petrogenesis has also been documented from the Southern Alps (e.g., Bonadiman et al., 1994).

We present in Figure 10 an interpretive model depicting the development of the rift-drift phases of the opening of the AlbanideHellenide Neotethys. This model implies a heterogeneous subcontinental mantle, in which the hydrated-depleted (SSZ-type) mantle portions left by the earlier Hercynian subduction events occur in the lithospheric mantle. In contrast, the OIB-type metasomatized portions are likely to be prominent in the asthenospheric mantle (Fig. 10a). We infer that convective thinning of the lithosphere might have brought SSZ-type mantle portions of the lithospheric mantle into direct contact with asthenospheric temperatures. These SSZ mantle portions, which had their solidus lowered by the addition of volatiles, underwent partial melting leading to the eruption of calc-alkaline and shoshonitic lavas starting in the early Triassic. Meanwhile, the uprising OIB-type metasomatized asthenospheric mantle underwent polybaric partial melting, which generated alkaline basalts associated in space and time with the calc-alkaline rocks (Fig. 10b). Subsequently, during the middle and late Triassic variably enriched (E-MORB and P-MORB) and depleted (N-MORB) magmas were also generated by partial melting in the spinel-facies mantle (Fig. 10b) and were erupted at the OCTZ. We deduce that N-MORBs were generated from uprising primitive asthenospheric sources, whereas E-MORBs and P-MORBs may have been generated either from variably metasomatized mantle portions, or by complex interactions (e.g., source contamination, magma mixing, etc.) between OIB-type metasomatized mantle and primitive asthenospheric mantle. The abundance of calc-alkaline rocks

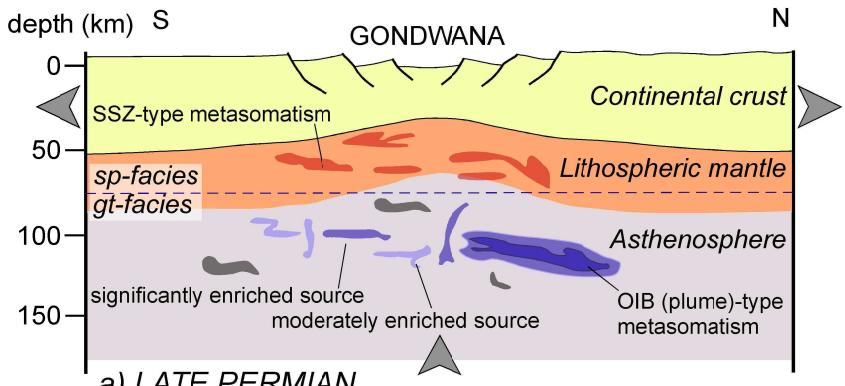

a) LATE PERMIAN

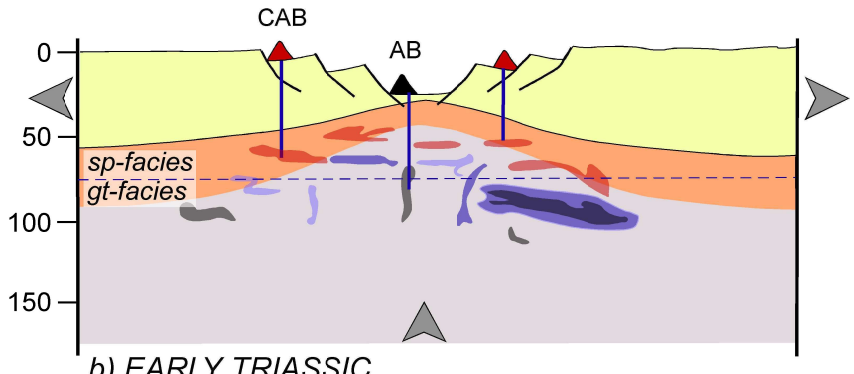

b) EARLY TRIASSIC

Composite ocean-continent transition zone crust with N-MORB, E-MORB, P-MORB and alkaline volcanics

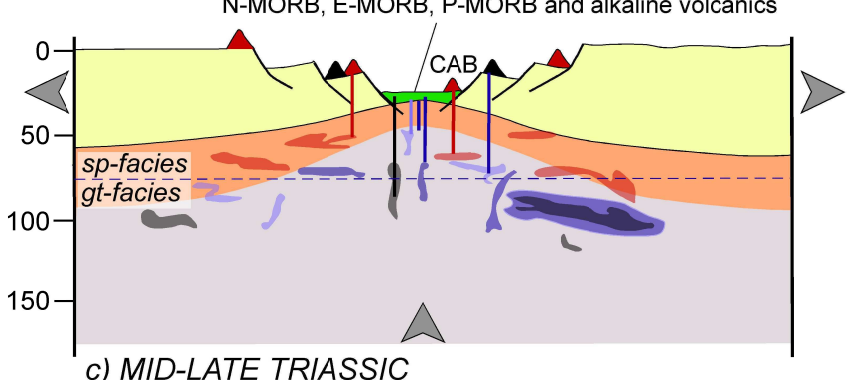

c) MID-LATE TRIASSIC

Figure 10. 2-D cartoons depicting the rift-drift, tectono-magmatic evolution of the Neotethyan Ocean in the Albanide-Hellenide sector. Abbreviations, SSZ: supra-subduction zone; OIB: ocean island basalt; CAB: calc-alkaline basalt; AB: alkaline basalt; MORB: midocean ridge basalt; $N$-: normal-type; $E$-: enriched-type; P-: plumetype; sp: spinel; gt: garnet. 
seems to have decreased from the middle to the late Triassic, and their occurrence appears to be more scattered compared to other rock types. This observation supports the hypothesis that SSZ-type metasomatized mantle portions were likely concentrated in the lithospheric mantle (Fig. 10a). By the end of the Triassic, the riftdrift phase gave way into seafloor spreading, and then the involvement of the sub-continental heterogeneous mantle sources in magmatism ceased. Consequently, the production of CABs, alkaline basalts, EMORBs and P-MORBs ended in the latest Triassic. From the early Jurassic onwards, the oceanic crust was generated entirely by the eruption of N-MORBs in response to uprising of sub-oceanic primitive mantle.

\section{Tectono-magmatic model for the rift-drift evolution of the Southern Neotethys}

Triassic ophiolitic rocks found in the northwestern section of the MZTZ include: (1) metalherzolites and metagabbros, crosscut by metabasaltic dikes. Structurally and compositionally, all these rocks resemble those similar ophiolitic subunits in the Alpine-Apennine system; (2) gabbros, dikes and pillow lavas ranging in composition from E-MORB to P-MORB and alkaline basalts. Similar basalts are also abundant in the Oman - UAE ophiolites south of the Persian Gulf (Chauvet et al., 2011).

A tectono-magmatic model for explaining the tectonic evolution of the Kermanshah and Sarve-Abad ophiolites has been proposed earlier by Saccani et al. (2013a, 2014). Here, we present a refined version of this model and summarize it, with a particular focus on the rift-drift development of the Southern Neotethys (Fig. 11). Prior to the Triassic, this region was part of a coherent Arabian-Iranian continental platform (Fig. 11a). The Sanandaj-Sirjan continental block started rifting away from Arabia in the early Triassic, or perhaps earlier, in the late Permian (Ghasemi and Talbot, 2006; Azizi and Moinevaziri, 2009; Saccani et al., 2013a; Whitechurch et al., 2013). As in the Western Tethys, the Sanandaj-Sirjan block was rifted from the northern margin of Arabia through asymmetrical passive extension (Fig. 11b), as also postulated by Dilek et al. (1991) and Dilek and Thy (1998) for the Kizildag ophiolite in southern Turkey that is interpreted to be the westward continuation of the Zagros ophiolites.

This simple shear extension led to the exhumation of the subcontinental mantle of Afro-Arabia, which is now represented by the Kermanshah metalherzolites. In the meantime, upwelling of the underlying asthenosphere in response to lithospheric extension and continental rifting was associated with limited partial melting of heterogeneous mantle sources, locally bearing garnet-pyroxenite relics (Fig. 11b). Similar to the Western Tethys, this magmatic episode led to the emplacement of volumetrically small quantities of gabbros and dikes with either N-MORB or G-MORB chemistry, originated from partial melting of a pure DMM source or a DMM source bearing garnet-pyroxenite relics, respectively. However, in contrast to the Western Tethys, rift-drift and seafloor spreading stages in the Southern Neotethys were also characterized by the marked influence of OIBtype (plume-type?) components associated with the uprising of asthenospheric mantle (Fig. 11c). The polybaric partial melting of an OIB-type enriched source led to the production of alkaline basalts (Fig. 11d1), whereas the partial melting of a MORB-type mantle, which was heterogeneously modified by OIB-type components, resulted in the production of both P- and E-MORBs (Figs. 11d2, d3).

The MZTZ ophiolites represent a particular case of a Continental Margin-type ophiolite, as introduced by Dilek and Furnes (2011,

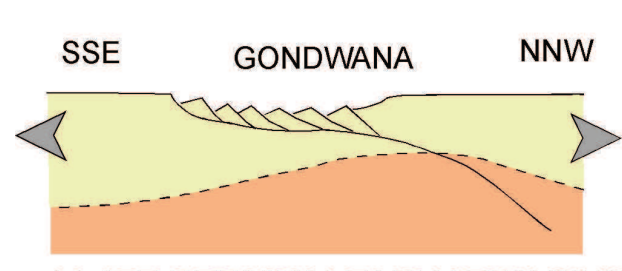

a) LATE PERMIAN-EARLY TRIASSIC

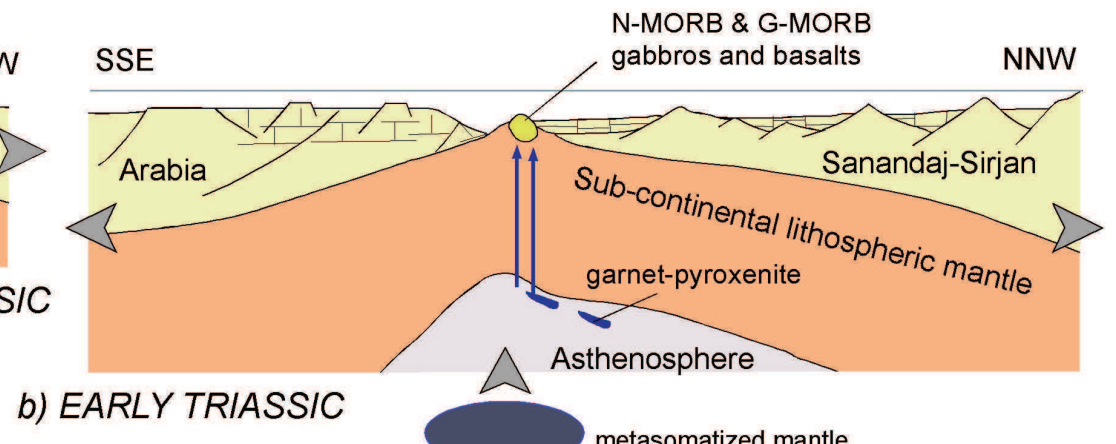

Not to scale

metasomatized mantle
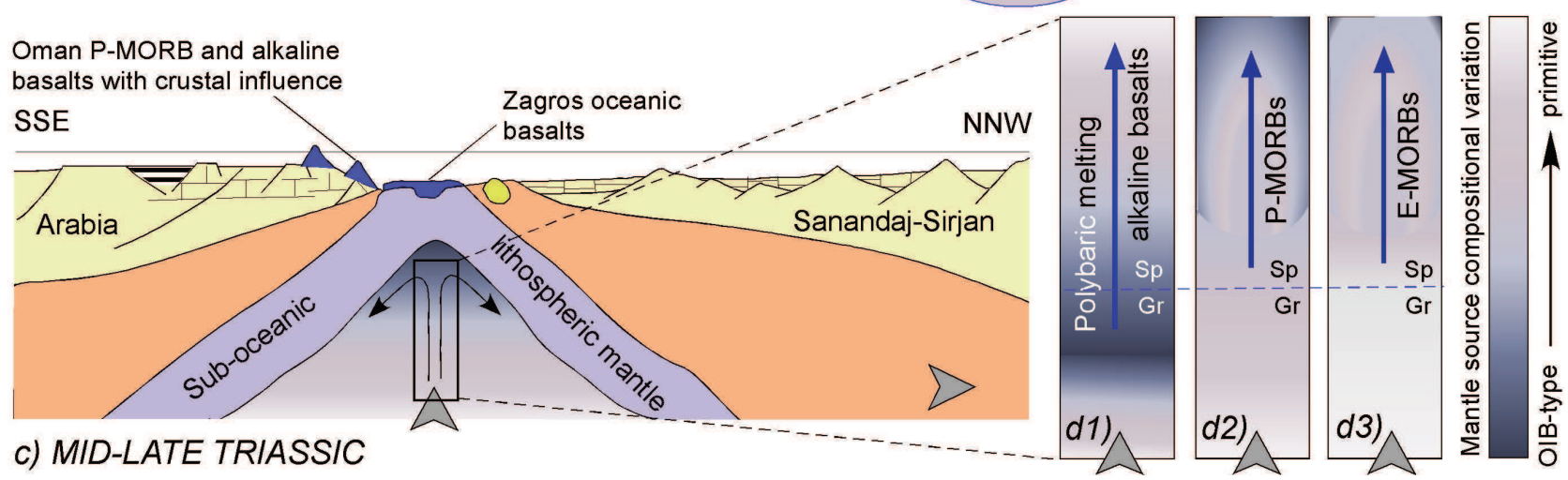

Figure 11. 2-D cartoons (modified from Saccani et al., 2013a) depicting the rift-drift, tectono-magmatic evolution of the Southern Neotethyan Ocean. Abbreviations, OIB: ocean island basalt; MORB: mid-ocean ridge basalt; $N$-: normal-type; E-: enriched-type; P-: plume-type; G: garnet-influenced type; Sp: spinel-facies mantle; Gt: garnet-facies mantle. 
2014). The mineral chemistry, geochemistry and isotopic data (Saccani et al., 2013a, 2014) suggest that these ophiolites may in fact represent the combination of Continental Margin- and Plume-type ophiolites. However, whether chemically enriched rocks represent derivation from OIB-like asthenosphere, or from a metasomatized mantle that was previously enriched by OIB-type components is unknown. In other words, the plume-type geochemical signature displayed by the middle Triassic MZTZ and Oman basalts does not necessarily provide evidence for the concomitant existence of an active mantle plume in the northern Gondwana area. Similar to our observations in the Triassic Neotethys section of the Albanide-Hellenide orogenic belt to the west, no clear evidence has been documented supporting the existence of a mantle plume in the Arabian-Iranian area during this time. Rather, a relatively small volume of plume-related volcanic rocks argues against the existence of a mantle plume. Chauvet et al. (2011) have suggested that the plume-type signature of the conjugate Oman lithospheric mantle was produced by pervasive metasomatism that was caused by the percolation of Permian plume-related melts through it (Lapierre et al., 2004). Mantle plume activities appear to have characterized the opening of Paleotethys during the Devonian-Carboniferous (see Xiao et al., 2008 and references therein; Xu et al., 2015). Therefore, in the lack of any direct evidence, we postulate that the OIB-type geochemical signature of the MZTZ ophiolites and Oman basalts was most likely inherited from previous mantle plume activities that occurred in the same area during the early Carboniferous opening of Paleotethys (Saccani et al., 2013b).

\section{Conclusions}

Continental Margin (CM) ophiolites consist of mafic-ultramafic and sedimentary rock assemblages developed during the continental breakup and embryonic oceanic crust generation at ocean-continent transition zones (OCTZ). These ophiolites are commonly highly dismembered and occur as tectonic slices in sub-ophiolitic mélanges. Their petrogenesis generally involves small degrees of partial melting of less depleted, continental lithospheric mantle and slowly upwelling asthenospheric mantle. Compositional heterogeneities in the subcontinental mantle strongly control the igneous stratigraphy and geochemical signatures of $\mathrm{CM}$ ophiolites. This heterogeneity is mainly a result of previous subduction events and/or earlier plume melt interactions with host peridotites, creating mantle contingency. This phenomenon is well illustrated by the occurrence of coeval calcalkaline basalts and shoshonites, N-MORBs, alkaline basalts, EMORBs, and P-MORBs in the Triassic CM ophiolites in the AlbanideHellenide belt. The inferred hydrated and depleted (SSZ-type) mantle residues in the Adria continental lithospheric mantle were the products of earlier Hercynian subduction events in the late Paleozoic. PMORBs and E-MORBs in the Zagros Continental Margin ophiolites were produced by partial melting of a MORB-type continental lithospheric mantle, which was heterogeneously modified by previous mantle plume events that took place during the early Carboniferous opening of Paleotethys.

Continental margin ophiolites are also diverse in terms of their internal structure and igneous stratigraphy. Some CM ophiolites are devoid of mantle peridotites, analogous to volcanic rifted margins. The Triassic Albanide-Hellenide ophiolites are a good example of this type, although they have volumetrically limited volcanic products and extensional calc-alkaline rocks, atypical of volcanic rifted margins. The CM ophiolites in the Zagros belt (e.g., Kermanshah ophiolite) contain continental lithospheric mantle lherzolites and gabbros crosscut by basaltic dikes and overlain by basaltic pillow lavas. This igneous stratigraphy is similar to the one displayed by the EL ophiolites (Western Tethys ophiolites) and documented from non-volcanic (or magma-poor) rifted margins. However, upwelling of an asthenospheric mantle with plume-influenced components resulted in the eruption of alkaline basalts and enriched sub-alkaline basalts in the Kermanshah $\mathrm{CM}$ ophiolites, a phenomenon that is unlike of magma-poor, rifted margins. These findings from the three cases of CM ophiolites we report in this study indicate that the fossil examples of the OCTZ crustal architecture and magmatic record do not invariably match with those of the two end-members of rifted margins (volcanic vs. nonvolcanic). The rates and kinematics of rifting, the existence (or not) of an active plume, upwelling rates of the asthenospheric mantle in response to lithospheric thinning, and the mode and scale of mantle heterogeneity caused by previous subduction and plume events strongly affect the rift architecture and the geochemical character of an OCTZ lithosphere.

\section{Acknowledgements}

Special thanks go to V. Bortolotti, G. Principi (University of Florence, Italy), M. Chiari (CNR-IGG, Florence, Italy), A. Festa (University of Torino, Italy), A. Photiades (I.G.M.E., Athens, Greece), I. Prempti, F. Mustafa (GjeoAlba, Tirane, Albania), M. Shallo (Chicago, USA), I. Milushi (Tirana Polytechnic University, Albania), and K. Allahyari (Shahid Beheshti University, Tehran, Iran) for their assistance during fieldwork in various ophiolites and ophiolite belts covered in this study. We would also like to thank H. Furnes and Ö. Elitok for their constructive and insightful reviews of our manuscript.

\section{References}

Agard, P., Omrani, L., Jolivet, L. and Mouthereau, F., 2005, Convergence history across Zagros (Iran): constraints from collisional and earlier deformation: International Journal of Earth Science (Geologische Rundschau), v. 94, pp. 401-419.

Alavi, M., 1994. Tectonics of the Zagros orogenic belt of Iran: new data and interpretations: Tectonophysics, v. 229, pp. 211-238.

Allahyari, K., Saccani, E., Pourmoafi, M., Beccaluva, L. and Masoudi, F., 2010, Petrology of mantle peridotites and intrusive mafic rocks from the Kermanshah ophiolitic complex (Zagros belt, Iran): Implications for the geodynamic evolution of the Neo-Tethyan oceanic branch between Arabia and Iran: Ofioliti, v. 35, pp. 71-90.

Allahyari, K., Saccani, E., Rahimzadeh, B. and Zeda, O., 2014, Mineral chemistry and petrology of highly magnesian ultramafic cumulates from the Sarve-Abad (Sawlava) ophiolites (Kurdistan, NW Iran): New evidence for boninitic magmatism in intra-oceanic fore-arc setting in the NeoTethys between Arabia and Iran: Journal of Asian Earth Sciences, v. 79: pp. 312-328, doi: 10.1016/j.jseaes.2013.10.005.

Anonymous, 1972, Penrose field conference on Ophiolites: Geotimes, v. 17, pp. 24-25.

Asvesta, A., 1992, Magmatism and associated sedimentation during the first stage of the opening of the Vardar oceanic basin in the Triassic time: Ph.D. Thesis, University of Thessaloniki, 439 p.

Aswad, K.J.A., Aziz, N.R.H. and Koy, H.A., 2011, Cr-spinel compositions in serpentinites and their implications for the petrotectonic history of the Zagros Suture Zone, Kurdistan Region, Iraq: Geological Magazine, v. 148, pp. 802-818, doi:10.1017/S0016756811000422.

Azizi, H. and Moinevaziri, H., 2009, Review of the tectonic setting of Cretaceous to Quaternary volcanism in northwestern Iran: Journal of Geodynamics, v. 47, pp. 167-179.

Babaie, H., Babaei, A., Ghazi, A.M. and Arvin, M., 2006, Geochemical, ${ }^{40} \mathrm{Ar} /{ }^{39} \mathrm{Ar}$ age, and isotopic data for crustal rocks of the Neyriz ophiolite, 
Iran: Canadian Journal of Earth Sciences, v. 43, pp. 57-70, doi:10.1139/ e05-111.

Balestro, G., Festa, A., Dilek, Y. and Tartarotti, P., 2015, Pre-Alpine extensional tectonics of a peridotite-localized oceanic core complex in the Late Jurassic, high pressure Monviso ophiolite (Western Alps): Episodes, v. 38, no. 4, pp. 266-282, doi:10.18814/epiiugs/2015/v38i4/82421.

Beaumont, C. and Ings, S.J., 2012, Effect of depleted continental lithosphere counterflow and inherited crustal weakness on rifting of the continental lithosphere: general results: Journal of Geophysical Research, v.117, B08407, http://dx.doi.org/10.1029/2012JB009203.

Bébien, J., Blanchet, R., Cadet, J.-P., Charvet, J., Chorowicz, J., Lapierre, H. and Rampnoux, J.-P., 1978, Le volcanisme Triasique des Dinarides en Yougoslavie: sa place dans l'évolution Géotectonique PeriMéditerranéenne: Tectonophysics, v. 47, pp. 159-176.

Berberian, M. and King, G.C.P., 1981, Towards a palaeogeography and tectonic evolution of Iran: Canadian Journal of Earth Sciences, v. 18, pp. 210265.

Bernoulli, D, Kälin, O and Patacca, E., 1979, A sunken continental margin of Tethys: the Northern and central Apennines, in Beaudoin, B. and Purser, B.H., eds, Sédimentation Jurassique W-européen: ASF Publication Spéciale, v. 1, pp. 197-210.

Bertotti, G, Picotti, V, Bernoulli, D and Castellarin, A., 1993, From rifting to drifting: tectonic evolution of the South-Alpine upper crust from the Triassic to the Early Cretaceous: Sedimentary Geology, v. 86, pp. 53-76.

Bonadiman, C., Coltorti, M. and Siena, F., 1994, Petrogenesis and T-fO2 estimates of Mt.Monzoni complex (Central Dolomites, Southern Alps): a Triassic shoshonotic intrusion in a transcurrent geodynamic setting: European Journal of Mineralogy, v. 6, pp. 943-966.

Bortolotti, V., Chiari, M., Kodra, A., Marcucci, M., Mustafa, F., Principi, G. and Saccani, E., 2004, New evidence for Triassic MORB magmatism in the northern Mirdita Zone ophiolites (Albania): Ofioliti, v. 29, pp. 243246.

Bortolotti, V., Chiari, M., Kodra, A., Martucci, M., Marroni, M., Mustafa, F., Prela, M., Pandolfi, L., Principi, G. and Saccani, E., 2006, Triassic MORB magmatism in the southern Mirdita zone (Albania): Ofioliti, v. 31, pp. 1-9.

Bortolotti, V., Chiari, M., Marcucci, M., Photiades, A., Principi, G. and Saccani, E., 2008, New geochemical and age data on the ophiolites from the Othrys area (Greece): Implication for the Triassic evolution of the Vardar ocean: Ofioliti, v. 33, pp. 135-151.

Bortolotti, V., Carras, N., Chiari, M., Fazzuoli, M., Marcucci, M., Nirta, G., Principi, G. and Saccani, E., 2009, The ophiolite-bearing melange in the Early Tertiary Pindos Flysch of Etolia (central Greece): Ofioliti, v. 34, pp. 83-94.

Bortolotti, V., Chiari, M., Marroni, M., Pandolfi, L., Principi, G. and Saccani, E., 2013, Geodynamic evolution of the ophiolites from Albania and Greece (Dinaric-Hellenic belt): One, two or more oceanic basins?: International Journal of Earth Sciences, v. 102, pp. 783-811, doi:10.1007/ s00531-012-0835-7.

Capedri, S., Toscani, L., Grandi, R., Venturelli, G., Papanikolaou, D. and Skarpelis, N.S., 1997, Triassic volcanic rocks of some type-localities from the Hellenides: Chemie der Erde, v. 57, pp. 257-276.

Chauvet F., Lapierre H., Maury R. C., Bosch D., Basile C., Cotten J., Brunet P. and Campillo S., 2011, Triassic alkaline magmatism of the Hawasina Nappes: Post-breakup melting of the Oman lithospheric mantle modified by the Permian Neotethyan Plume: Lithos, v. 122, pp. 122-136.

Chenin, P. and Beaumont, C., 2013, Influence of offset weak zones on the development of rift basins: activation and abandonment during continental extension and breakup: Journal of Geophysical Research, v. 118, pp. 1698-1720, http://dx.doi.org/10.1002/jgrb.50138.

Chiari, M., Marcucci, M., Cortese, G., Ondrejickova, A. and Kodra, A., 1996, Triassic radiolarian assemblages in the Rubik area and Cukali zone, Albania: Ofioliti, v. 21, pp. 77-84.

Chiari, M., Bortolotti, V., Marcucci, M., Photiades, A., Principi, G. and Saccani, E., 2012, Radiolarian biostratigraphy and geochemistry of the Koziakas massif ophiolites (Greece): Bulletin de la Societé géologique de France, v. 183, pp. 287-306.

Coffin, M.F. and Eldholm. O., 1994, Large igneous provinces: Crustal structure, dimensions, and external consequences: Reviews of Geophysics, v. 32, pp. 1-36.

Coffin, M.F., Pringle, M.S., Duncan, R.A., Gladczenko, T.P., Storey, M., Mueller, R.D. and Gahagan L.A., 2002, Kerguelen hotspot magma output since 130 Ma. Journal of Petrology, v. 43, pp. 1121-1139.

Coleman, R.G., 1971, Plate tectonic emplacement of upper mantle peridotites along continental edges: Journal of Geophysical Research, v. 76, pp. 12121222, doi: 10.1029/JB076i005p01212.

Compagnoni, R., 2003, HP metamorphic belt of the western Alps: Episodes, v. 26 , pp. $200-204$

Cortesogno, L. and Gaggero, L., 1992, The basaltic dikes in the Bracco gabbroic massif: petrology of the earliest phases of basaltic activity in the northern Apennines ophiolites: Ofioliti, v. 17, pp. 183-198.

Desmons, J. and Beccaluva, L., 1983, Mid-ocean ridge and island-arc affinities in ophiolites from Iran: palaeographic implications: Chemical Geology, v. 39, pp. 39-63.

Desmurs, L., Muntener, O. and Manatschal, G., 2002, Onset of magmatic accretion within a magma-poor rifted margin: a case study from the Platta ocean-continent transition, eastern Switzerland: Contribution to Mineralogy and Petrology, v. 144, pp. 365-382, doi 10.1007/s00410002-0403-4

Dewey, J.F., and Bird, J.M., 1971, The origin and emplacement of the ophiolite suite: Appalachian ophiolites in Newfoundland: Journal of Geophysical Research, v. 76, pp. 3179-3206, doi: 10.1029/JB076i014 p03179.

Dilek, Y., 2003a, Ophiolite concept and its evolution: Geological Society of America Special Paper, v. 373, pp. 1-16.

Dilek, Y., 2003b, Ophiolite pulses, plumes and orogeny: Geological Society, London, Special Publications, v. 218, p. 9-19.

Dilek, Y., Moores, E.M., Delaloye, M. and Karson, J.A., 1991, Amagmatic extension and tectonic denudation in the Kizildag Ophiolite, southern Turkey: Implications for the evolution of Neotethyan oceanic crust: Ministry of Petroleum and Minerals, Sultanate of Oman, pp. 485500

Dilek, Y. and Rowland, J.C., 1993, Evolution of a conjugate passive margin pair in Mesozoic southern Turkey: Tectonics, v. 12, pp. 954-970, doi: 10.1029/93TC01060.

Dilek, Y. and Thy, P., 1998, Structure, petrology and seafloor spreading tectonics of the Kizildag ophiolite, Turkey: Geological Society, London, Special Publications, v. 148, p. 43-69.

Dilek, Y., Moores, E.M., and Furnes, H., 1998, Structure of modern oceanic crust and ophiolites and implications for faulting and magmatism at oceanic spreading centers: American Geophysical Union Monograph, v. 106 , p. $219-265$.

Dilek, Y., Thy, P., Hacker, B., and Grundvig, S., 1999, Structure and petrology of Tauride ophiolites and mafic dike intrusions (Turkey): Implications for the Neotethyan ocean: Geological Society of America Bulletin, v. 111, p. $1192-1216$.

Dilek, Y. and Robinson, P.T., 2003. Ophiolites in Earth History: Introduction: Geological Society, London, Special Publication, v. 218, pp. 1-8, doi: 10.1144/gsl.sp.2003.218.01.01.

Dilek, Y., Furnes, H., and Shallo, M., 2007, Suprasubduction zone ophiolite formation along the periphery of Mesozoic Gondwana: Gondwana Research, v. 11, p. 435-475.

Dilek, Y., Furnes, H., and Shallo, M., 2008, Geochemistry of the Jurassic Mirdita Ophiolite (Albania) and the MORB to SSZ evolution of a marginal basin oceanic crust: Lithos, v. 100, pp. 174-209.

Dilek, Y. and Sandvol, E., 2009, Seismic structure, crustal architecture and tectonic evolution of the Anatolian-African Plate Boundary and the Cenozoic Orogenic Belts in the Eastern Mediterranean Region: Geological Society, London, Special Publications, v. 327, p. 127-160.

Dilek, Y. and Furnes, H., 2011, Ophiolite genesis and global tectonics: Geochemical and tectonic fingerprinting of ancient oceanic lithosphere: Geological Society of America Bulletin, v. 123, pp. 387-411, doi: 10.1130/ B30446.1.

Dilek, Y. and Furnes, H., 2014, Ophiolites and their origins: Elements, v. 10, pp. 93-100, doi: 10.2113/gselements.10.2.93.

Durand-Delga, M., 1984, Principaux traits de la Corse alpine et corrélations avec les Alpes ligures: Memorie della Società Geologica Italiana, v. 28, pp. 285-329.

Eldholm, O., Gladczenko, T.P., Skogseid, J., and Planke, S., 2000, Atlantic volcanic margins: a comparative study: Geological Society of London Special Publication, v. 167, pp. 411-428.

Festa, A., Balestro, G., Dilek, Y., and Tartarotti, P., 2015, A Jurassic Oceanic Core Complex in the High-P Monviso Ophiolite (Western Alps, NW Italy): Lithosphere, v. 7, No. 6, pp. 646-652. 
Froitzheim, N. and Manatschal, G., 1996, Kinematics of Jurassic rifting, mantle exhumation, and passive-margin formation in the Austroalpine and Penninic nappes (eastern Switzerland): Geological Society of America Bulletin, v. 108, pp. 1120-1133.

Ghasemi, A. and Talbot, C.J., 2006, A new tectonic scenario for the SanandajSirjan Zone (Iran): Journal of Asian Earth Sciences, v. 26, pp. 683-693.

Ghazi, A.M. and Hassanipak, A.A., 1999, Geochemistry of subalkaline and alkaline extrusives from the Kermanshah ophiolite, Zagros Suture Zone, western Iran: implications on Tethyan plate tectonics: Journal of Asian Earth Science, v. 17, pp. 319-332.

Glennie, K.W., 2000, Cretaceous tectonic evolution of Arabia's eastern plate margin: a tale of two oceans: SEPM (Society for Sedimentary Geology) Special Publication, v. 69, pp. 9-20.

Hinz, K., 1981, A hypothesis on terrestrial catastrophes: wedges of very thick oceanward dipping layers beneath passive continental margins - their origin and paleoenvironmental significance: Geologisches Jahrbuch Reihe E, pp. 3-28.

Huismans, R.S. and Beaumont, C., 2007, Roles of lithospheric strain softening and heterogeneity in determining the geometry of rifts and continental margins: Geological Society London Special Publication, v. 282, pp. 111138.

Jones, G. and Robertson, A.H.F., 1991, Tectono-stratigraphic evolution of the Mesozoic Pindos ophiolite and related units, northwestern Greece: Journal of the Geological Society London, v. 148, pp. 267-288.

Jones, C.H., Wernicke, B.P., Farmer, G.L., Walker, J.D., Coleman, D.S., McKenna, L.W. and Perry, F.V., 1992, Variations across and along a major continental rift: an interdisciplinary study of the Basin and Range province, western USA: Tectonophysics, v. 213, pp. 57-96.

Kerr, A.C., 1994, Lithospheric thinning during the evolution of continental large igneous provinces: A case study from the North Atlantic Tertiary Province. Geology, v. 22, pp. 1027-1030.

Kusznir, N.J. and Karner, G.D., 2007, Continental lithospheric thinning and breakup in response to upwelling divergent mantle flow: application to the Woodlark, Newfoundland and Iberia margins: Geological Society London Special Publication, v. 282, pp. 389-419.

Lagabrielle, Y. and Cannat, M., 1990, Alpine Jurassic ophiolites resemble the modern central Atlantic basement: Geology, v. 18, pp. 319-322.

Lapierre, H., Samper, A., Bosch, D., Maury, R.C., Béchennec, F., Cotten, J., Demant, A., Brunet, P., Keller, F. and Marcoux, J., 2004, The Tethyan plume: geochemical diversity of Middle Permian basalts from the Oman rifted margin: Lithos, v. 74, pp. 167-198.

Lemoine, M. and Trumpy, R., 1987, Pre-oceanic rifting in the Alps: Tectonophysics, v. 133, pp. 305-320.

Lister, G.S., Etheridge, M.A. and Symonds, P.A., 1991, Detachment models for the formation of passive continental margins: Tectonics, v. 10, pp. $1038-1064$

Lister, G., and Forster, M., 2009, Tectonic mode switches and the nature of orogenesis: Lithos, v. 113, pp. 274-291, doi: 10.1016/j.lithos.2008.10. 024 .

Liu, F., Yang, J.-S., Dilek, Y., Xu, Z.-Q., Xu, X.-Z., Liang, F.-H., Chen, S.-Y., and Lian, D.-Y., 2015, Geochronology and geochemistry of basaltic lavas in the Dongbo and Purang ophiolites of the Yarlung-Zangbo Suture zone: Plume-inûuenced continental margin-type oceanic lithosphere in southern Tibet: Gondwana Research, v. 27, p. 701-718

Liu, Y., Gao, S., Lee, C.-T.A., Hu, S., Liu, X., and Yuan, H., 2005, Meltperidotite interactions: Links between garnet pyroxenite and high-Mg\# signature of continental crust: Earth and Planetary Science Letters, v. 234 , pp. $39-57$.

Lustrino, M., Melluso, L. and Morra, V., 2002, The transition from alkaline to tholeiitic magmas: a case study from the Orosei-Dorgali Pliocene volcanic district (NE Sardinia, Italy): Lithos, v. 63, pp. 83-113.

Malavieille, J., Chemenda, A. and Larroque, C., 1998, Evolutionary model for Alpine Corsica: mechanism for ophiolite emplacement and exhumation of high-pressure rocks: Terra Nova, v. 10, pp. 317-322.

Manatschal, G., and Müntener, O., 2009, A type sequence across an ancient magma-poor ocean-continent transition: The example of the western Alpine Tethys ophiolites: Tectonophysics, v. 473, pp. 4-19, doi: 10.1016 j.tecto.2008.07.021

Marroni, M., Molli, G., Montanini, A. and Tribuzio, R., 1998, The association of continental crust rocks with ophiolites in the Northern Apennines (Italy): implications for the continent-ocean transition in the Western Tethys: Tectonophysics, v. 292, pp. 43-66.
Marroni, M., Molli, G., Ottria, G. and Pandolfi, L., 2001, Tectono-sedimentary evolution of the External Liguride Units (Northern Apennine, Italy): insights in the precollisional history of a fossil ocean-continent transition zone: Geodinamica Acta, v. 14, pp. 307-320.

Marroni, M. and Pandolfi, L., 2003, Deformation history of the ophiolite sequence from Balagne Nappe (Northern Corsica): insights in the tectonic evolution of the alpine Corsica: Geological Journal, v. 38, pp. 67-83.

Marroni, M., Pandolfi. L. and Meneghini F., 2004, From accretion to exhumation in a fossil accretionary wedge: a case history from Gottero Unit (Northern Apennines, Italy): Geodinamica Acta, v. 17, pp. 41-53.

Marroni, M. and Pandolfi, L., 2007, The architecture of the Jurassic LigurePiemontese oceanic basin: tentative reconstruction along the Northern Apennine - Alpine Corsica transect: International Journal of Earth Sciences, v. 96, pp. 1059-1078.

Marroni, M., Meneghini, F., and Pandolfi, L., 2010, Anatomy of the LigurePiemontese subduction system: evidences from Late Cretaceous-Middle Eocene convergence-related deposits from Northern Apennines (Italy): International Geology Review, v. 10-12, pp. 1160-1192.

Meneghini, F., Marroni, M., Moore, J.C., Pandolfi, L. and Rowe, C.D., 2009, The process of underplating in the geologic record: structural diversity between the Franciscan Complex (California), the Kodiak Complex (Alaska) and the Internal Ligurian Units (Italy): Geological Journal, v. 44 , pp. $126-152$.

Menzies, M.A., Klemperer, S.L., Ebinger, C.J. and Baker, J., 2002, Characteristics of volcanic rifted margins: Geological Society of America Special Paper, v. 362, pp. 1-14.

Monjoie, P., Lapierre, H., Tashko, A., Mascle, G.H., Dechamp, A., Muceku, B. and Brunet, P., 2008, Nature and origin of the Triassic volcanism in Albania and Othrys: a key to understanding the Neotethys opening? Bulletin de la Societé géologique de France, v. 179, pp. 411-425.

Montanini, A., Tribuzio, R. and Anczkiewicz, R., 2006, Exhumation history of a garnet pyroxenite bearing mantle section from a continent-ocean transition (Northern Apennine ophiolites, Italy): Journal of Petrology, v. 47, pp. 1943-1971, doi:10.1093/petrology/eg1032.

Montanini, A., Tribuzio, R. and Vernia, L., 2008. Petrogenesis of basalts and gabbros from an ancient continent-ocean transition (External Liguride ophiolites, Northern Italy): Lithos, v. 101, pp. 453-479, doi: 10.1016/ j.lithos.2007.09.007.

Mouthereau, F., Lacombe, O. and Vergés, J., 2012, Building the Zagros collisional orogen: Timing, strain distribution and the dynamics of Arabia/ Eurasia plate convergence: Tectonophysics, v. 532-535, pp. 27-60, http:/ /dx.doi.org/10.1016/j.tecto.2012.01.022.

Mutter, J.C., Talwani, M. and Stoffa, P.L., 1982, Origin of seaward-dipping reflectors in oceanic crust off the Norwegian margin by "subaerial seafloor spreading": Geology, v. 10, pp. 353-357.

Ozsvart, P., Dosztaly, L., Migiros, G., Tselepidis, V. and Kovacs, S., 2011, New radiolarian biostratigraphic age constraints on Middle Triassic basalts and radiolarites from the Inner Hellenides (Northern Pindos and Othris Mountains, Northern Greece) and their implications for the geodynamic evolution of the early Mesozoic Neotethys: International Journal of Earth Science, v. 101, pp. 1487-1501, doi:10.1007/s00531010-0628-9.

Pamiç, J., 1984, Triassic magmatism of the Dinarides in Yugoslavia: Tectonophysics, v. 109, pp. 273-307.

Pearce, J.A., 1982, Trace element characteristics of lavas from destructive plate boundaries: in Thorpe, R.S., ed, Andesites: New York, J. Wiley and Sons, pp. 525-548

Pe-Piper, G., 1983, The Triassic volcanic rocks of Tyros, Zarouhla, Kalamae, and Epidavros, Peloponnese, Greece: Schweizerische Mineralogische und Petrographische Mitteilungen, v. 63, pp. 249-266.

Pe-Piper, G., 1998, The nature of Triassic extension-related magmatism in Greece: Evidence from $\mathrm{Nd}$ and $\mathrm{Pb}$ isotope geochemistry: Geological Magazine, v. 135, pp. 331-348.

Pe-Piper, G. and Panagos, A.G., 1989, Geochemical characteristics of the Triassic volcanic rocks of Evia: Petrogenetic and tectonic Implications: Ofioliti, v. 14, pp. 33-50.

Pe-Piper, G. and Mavroniki, M., 1990, Petrology, geochemistry and regional significance of the Triassic volcanic rocks of the Western Parnassos isopic zone of Greece: Ofioliti, v. 15, pp. 269-285.

Pe-Piper, G. and Piper, D.J.W., 1991, Early Mesozoic oceanic subductionrelated volcanic rocks, Pindos basin, Greece: Tectonophysics, v. 192, pp. 273-292. 
Pe-Piper, G. and Kotopouli, C.N., 1991, Geochemical characteristics of the Triassic igneous rocks of the Island of Samos, Greece: Neues Jahrbruch fur Mineralogie Abhandlungen, v. 162, pp. 135-150.

Péron-Pinvidic, G. and Manatschal, G., 2009, The final rifting evolution at deep magma-poor passive margins from Iberia-Newfoundland: A new point of view: International Journal Earth Science, v. 98, pp. 1581-97.

Photiades, A., Saccani, E. and Tassinari, R., 2003, Petrogenesis and tectonic setting of volcanic rocks from the Subpelagonian ophiolitic mélange in the Agoriani area (Othrys, Greece): Ofioliti, v. 28, pp. 121-135.

Piccardo, G.B., 2008, The Jurassic Ligurian Tethys, a fossil ultraslowspreading ocean: the mantle perspective: Geological Society of London Special Publication, v. 293, pp. 11-34.

Planke, S., Skogseid, J., and Eldholm, O., 1991, Crustal structure off Norway, $62^{\circ}$ to $70^{\circ}$ north: Tectonophysics, v. 189 , pp. 91-107.

Rajabzadeh, M.A. and Dehkordi, T.N., 2013, Investigation on mantle peridotites from Neyriz ophiolite, south of Iran: geodynamic signals: Arabian Journal of Geoscience, v. 6, pp. 4445-4461, doi: 10.1007/s12517012-0687-2.

Rampone, E., Hofmann, A.W., Piccardo, G.B., Vannucci, R., Bottazzi, P. and Ottolini, L., 1995, Petrology, mineral and isotope geochemistry of the External Liguride peridotites (Northern Apennines, Italy): Journal of Petrology, v. 36, pp. 81-105.

Rampone, E., Hofmann, A.W. and Raczek, I., 1998, Isotopic constraints within the Internal Liguride ophiolites (N. Italy): The lack of a genetic mantlecrust link: Earth and Planetary Science Letters, v. 163, pp.175-189.

Rampone, E., Romairone, A., Abouchami, W., Piccardo, G.B., and Hofmann, A.W., 2005, Chronology, petrology, and isotope geochemistry of the ErroTobbio peridotites (Ligurian Alps, Italy): Records of late Palaeozoic lithospheric extension: Journal of Petrology, v. 46, pp. 799-827, doi: 10.1093/petrology/egi001.

Rampone, E. and Hofmann, A.W., 2012, A global overview of isotopic heterogeneities in the oceanic mantle: Lithos, v. 148, pp. 247-261, doi:10.1016/j.lithos.2012.06.018

Ricou, L.E., 1994, Tethys reconstructed - plates, continental fragments and their boundaries since 260-Ma from Central-America to South-eastern Asia: Geodinamica Acta, v. 7, pp. 169-218.

Robertson, A.H.F., 2007, Overview of tectonic settings related to the rifting and opening of Mesozoic ocean basins in the Eastern Tethys: Oman, Himalayas and Eastern Mediterranean regions: Geological Society, London Special Publication, v. 282, pp. 325-389.

Robertson, A.H.F., Clift, P.D.C., Degnan, P.J. and Jones, G., 1991, Palaeogeographic and palaeotectonic evolution of the Eastern Mediterranean Neotethys: Palaeogeography, Palaeoclimatology, Palaeoecology, v. 87, pp. 289-343.

Royden, L. and Keen, C.E., 1980, Rifting processes and thermal evolution of the continental margin of eastern Canada determined from subsidence curves: Earth and Planetary Science Letters, v. 51, pp. 343-361.

Sabzehei, M., Gourabjiri, A. and Eslamdoust, F., 1968, Geological map of Paweh and West Paweh, 1/100.000 scale: Geological Survey of Iran, Tehran.

Saccani, E., 2015, A new method of discriminating different types of postArchean ophiolitic basalts and their tectonic significance using Th-Nb and Ce-Dy-Yb systematics: Geoscience Frontiers, v.6, pp. 481-501, http:/ /dx.doi.org/10.1016/j.gsf.2014.03.006.

Saccani, E., Padoa, E. and Tassinari, R., 2000, Preliminary data on the Pineto gabbroic massif and Nebbio Basalts: progress toward the geochemical characterization of Alpine Corsica Ophiolites: Ofioliti, v. 25, pp. 75-85.

Saccani, E., Photiades, A. and Padoa, E., 2003a, Geochemistry, petrogenesis and tectono-magmatic significance of volcanic and subvolcanic rocks from the Koziakas Mélange (Western Thessaly, Greece): Ofioliti, v. 28, pp. 43-57.

Saccani, E., Padoa, E. and Photiades, A., 2003b, Triassic mid-ocean ridge basalts from the Argolis Peninsula (Greece): new constraints for the early oceanization phases of the Neo-Tethyan Pindos basin: Geological Society London Special Publications, v. 218, pp. 109-127.

Saccani, E. and Photiades, A., 2005, Petrogenesis and tectono-magmatic significance of volcanic and subvolcanic rocks in the Albanide-Hellenide ophiolitic mélanges: The Island Arc, v. 14, pp. 494-516.

Saccani, E., Principi, G., Garfagnoli, F. and Menna, F., 2008a, Corsica ophiolites: Geochemistry and petrogenesis of basaltic and metabasaltic rocks: Ofioliti, v. 33, pp. 187-207.

Saccani, E., Photiades, A., Santato, A. and Zeda, O., 2008b, New evidence for supra-subduction zone ophiolites in the Vardar zone from the Vermion massif (northern Greece): Implication for the tectono-magmatic evolution of the Vardar oceanic basin: Ofioliti, v. 33, pp. 65-85.

Saccani, E., Allahyari, K., Beccaluva, L. and Bianchini, G., 2013a, Geochemistry and petrology of the Kermanshah ophiolites (Iran): Implication for the interaction between passive rifting, oceanic accretion, and plume-components in the Southern Neo-Tethys Ocean: Gondwana Research, v. 24, pp. 392-411, http://dx.doi.org/10.1016/j.gr.2012.10.009.

Saccani, E., Azimzadeh, Z., Dilek, Y. and Jahangiri, A., 2013b, Geochronology and Petrology of the Early Carboniferous Misho Mafic Complex (NW Iran), and Implications for the Melt Evolution of Paleo-Tethyan Rifting in Western Cimmeria: Lithos, v. 162-163, pp. 264-278.

Saccani, E., Allahyari, K. and Rahimzadeh, B., 2014, Petrology and geochemistry of mafic magmatic rocks from the Sarve-Abad ophiolites (Kurdistan region, Iran): Evidence for interaction between MORB-type asthenosphere and OIB-type components in the southern Neo-Tethys Ocean: Tectonophysics, v. 621, pp. 132-147, doi:10.1016/j.tecto.2014. 02.011 .

Shafaii Moghadam, H., Stern, R.J., Chiaradia, M. and Rahgoshay, M., 2013, Geochemistry and tectonic evolution of the Late Cretaceous GogherBaft ophiolite, central Iran: Lithos, v. 168-169, pp. 33-47, doi: 10.1016/ j.lithos.2013.01.013.

Shallo, M. and Dilek, Y., 2003, Development of the ideas on the origin of Albanian ophiolites: Geological Society of America Special Paper, v. 373, pp. 351-364.

Schilling, J.-G., Zajac, M., Evans, R., Johnston, T., White, W., Devine, J.D. and Kingsley, R., 1983, Petrologic and geochemical variations along the Mid-Atlantic Ridge: American Journal of Science, v. 283, pp. 510-586.

Sibuet, J.-C. and Tucholke, B.E., 2013, The geodynamic province of transitional litho-sphere adjacent to magma-poor continental margins: Geological Society of London Special Publication, v. 369, pp. 429-452, http://dx.doi.org/10.1144/SP369.15.

Sinton, J.M. and Detrick, R.S., 1992, Mid-ocean ridge magma chambers: Journal of Geophysical Research, v. 97, pp. 197-216.

Skogseid, J., 2001, Volcanic margins: geodynamic and exploration aspects: Marine and Petroleum Geology, v. 18, pp. 457-461.

Stöcklin, J., 1968, Structural history and tectonics of Iran: A review: Bulletin of the American Association of Petroleum Geologists, v. 52, pp. 12291258 .

Stoppa, F., 1985, Problematiche petrologiche e geologiche delle prasiniti di Punta Bianca (La Spezia): Memorie della Società Geologia Italiana, v. 30, pp. 127-134.

Storey, M., Duncan, R.A. and Tegner C., 2007, Timing and duration of volcanism in the North Atlantic Igneous Province: implications for geodynamics and links to the Iceland hotspot. Chemical Geology, v. 241, pp. 264-281.

Sun, S.-s. and McDonough, W.F., 1989, Chemical and isotopic-systematics of oceanic basalts: implications for mantle composition and processes: Geological Society of London Special Publications, v. 42, pp. 313-345.

Tashko, A., Mascle, G.H., Muceku, B. and Lapierre, H., 2007, Nd, Pb isotope and trace element signatures of the Triassic volcanism in Albania. The relationship to the NeoTethys opening: Albanian Journal of Natural and Technical Science, v.1, pp. 3-23.

Van Avendonk, H.J.A., Lavier, L.L., Shillington, D.J. and Manatschal, G., 2009: Extension of continental crust at the eastern Grand Banks, Newfoundland: Tectonophysics, v. 468, pp. 131-148. http://dx.doi.org/ 10.1016/j.tecto.2008.05.030.

Vannucci, R., Rampone, E., Piccardo, G.B., Ottolini, L. and Bottazzi, P., 1993, Ophiolitic magmatism in the Ligurian Tethys: An ion microprobe study of basaltic clinopyroxenes: Contribution to Mineralogy and Petrology, v. 115, pp. 123-137.

Venturelli, G., Capedri, S., Thorpe, R.S. and Potts, P.J., 1979, Rare-earth and other element distribution in some ophiolitic metabasalts of Corsica, Western Mediterranean: Chemical Geology, v. 24, pp. 339-353.

Wernicke, B., 1981, Low-angle normal faults in the Basin and Range provincenappe tectonics in an extending orogeny: Nature, v. 291, pp. 645-648.

Whitechurch, H., Omrani, J., Agard, P., Humbert, F., Montigny, R. and Jolivet L., 2013, Evidence for Paleocene-Eocene evolution of the foot of the Eurasian margin (Kermanshah ophiolite, SW Iran) from back-arc to arc: Implications for regional geodynamics and obduction: Lithos, v. 182183, pp. 11-32.

Whitemarsh, R.B., Manatschal, G. and Minshull, T.A., 2001, Evolution of 
magma-poor continental margins: From final rifting to seafloor spreading: Nature, v. 413, pp. 150-154.

Winterer, E.L. and Bosellini A., 1981, Subsidence and sedimentation on Jurassic passive continental margin, Southern Alps, Italy: American Association of Petroleum Geologists Bulletin, v. 65, pp. 394-421.

Wooler, D.A., Smith, A.G. and White, N., 1992, Measuring lithospheric stretching on Tethyan passive margins: Journal of the Geological Society London, v. 149, pp. 517-532.

Workman, R.K. and Hart, S.R., 2005, Major and trace element composition of the depleted MORB mantle (DMM): Earth and Planetary Science Letters, v. 231, pp. 53-72.

Xiao, L., He, Q., Pirajno, F., Ni, P., Du, J., Wei, Q., 2008, Possible correlation between a mantle plume and the evolution of Paleo-Tethys Jinshajiang Ocean: Evidence from a volcanic rifted margin in the Xiaru-Tuoding area, Yunnan, SW China: Lithos, v. 100, pp. 112-126.

Xu, Z.Q., Dilek, Y., Cao, H., Yang, J.S., Robinson, P., Ma, C.Q., Li, H., Jolivet, M., Roger, F., Chen, X.J., 2015, Paleo-Tethyan Evolution of Tibet as Recorded in the East Cimmerides and West Cathaysides: Journal of Asian Earth Sciences, v. 105, pp. 320-337, doi: 10.1016/j.jseaes.2015. 01.021.

Yang, G.X. and Dilek, Y., 2015, OIB and P-Type Ophiolites along the YarlungZangbo Suture Zone (YZSZ), Southern Tibet: Poly-Phase melt history and mantle sources of the Neotethyan Oceanic Lithosphere: Episodes, v. 38 , No. 4, pp. 250-265, doi:10.18814/epiiugs/2015/v38i4/82420.

APPENDIX - A

Initial compositions and melting modes of different sources, as well as the partition coefficients (KD) used in the melting models in Figs. 5, 7, 8c.

\begin{tabular}{|c|c|c|c|c|c|}
\hline \multicolumn{6}{|c|}{ Source composition } \\
\hline & $\begin{array}{c}\text { Depleted } \\
\text { MORB mantle }\end{array}$ & $\begin{array}{c}\text { Enriched } \\
\text { source } 1(\mathrm{ES} 1)\end{array}$ & $\begin{array}{c}\text { Enriched } \\
\text { source } 2(\mathrm{ES} 2)\end{array}$ & $\begin{array}{l}\text { Ocean } \\
\text { island basalt }\end{array}$ & $\begin{array}{c}\text { Garnet } \\
\text { pyroxenite }\end{array}$ \\
\hline Th (ppm) & 0.0068 & 0.08 & 0.1 & 0.18 & 0.017 \\
\hline $\mathrm{Nb}(\mathrm{ppm})$ & 0.1277 & 0.6 & 0.8 & 1.5 & 0.48 \\
\hline \multirow[t]{2}{*}{$\mathrm{Yb}(\mathrm{ppm})$} & 0.353 & 0.353 & 0.353 & 0.353 & 0.84 \\
\hline & ol & opx & cpx & gt & $\mathrm{sp}$ \\
\hline \multicolumn{5}{|l|}{ Source Mode } & \\
\hline $\begin{array}{l}\text { spinel-facies }^{(b)} \\
\text { garnet-pyroxenite }\end{array}$ & 0.578 & 0.27 & $\begin{array}{c}0.119 \\
0.7\end{array}$ & 0.3 & 0.033 \\
\hline \multicolumn{6}{|l|}{ Melting Mode } \\
\hline $\begin{array}{l}\text { sp-facies }{ }^{(b)} \\
\text { garnet-pyroxenite }\end{array}$ & 0.1 & 0.27 & $\begin{array}{l}0.5 \\
0.7\end{array}$ & 0.3 & 0.13 \\
\hline \multicolumn{6}{|l|}{ KD } \\
\hline $\mathrm{Yb}$ & $0.0015^{(1)}$ & $0.049^{(1)}$ & $0.28^{(1)}$ & $5.73^{(2)}$ & \\
\hline $\mathrm{Th}$ & $0.0001^{(1)}$ & $0.058^{(3)}$ & $0.00026^{(1)}$ & $0.0001^{(1)}$ & \\
\hline $\mathrm{Nb}$ & $0.063^{(4)}$ & $0.01^{(5)}$ & $0.05^{(1)}$ & $0.0003^{(6)}$ & \\
\hline \multicolumn{6}{|l|}{ spinel-facies } \\
\hline $\mathrm{Yb}$ & $0.0015^{(1)}$ & $0.049^{(1)}$ & $0.28^{(1)}$ & & $0.01^{(1)}$ \\
\hline $\mathrm{Th}$ & $0.0001^{(1)}$ & $0.058^{(3)}$ & $0.00026^{(1)}$ & & $0.0024^{(7)}$ \\
\hline $\mathrm{Nb}$ & $0.063^{(4)}$ & $0.003^{(5)}$ & $0.05^{(1)}$ & & $0.001^{(8)}$ \\
\hline \multicolumn{6}{|l|}{ garnet-pyroxenite } \\
\hline $\mathrm{Yb}$ & & & $0.43^{(9)}$ & $7.86^{(10)}$ & \\
\hline Th & & & $0.0083^{(11)}$ & $0.001^{(10)}$ & \\
\hline $\mathrm{Nb}$ & & & $0.05^{(1)}$ & $0.0008^{(10)}$ & \\
\hline
\end{tabular}

Abbreviations, ol: olivine; opx: orthopyroxene; cpx: clinopyroxene; gt: garnet; sp: spinel.

\section{References}

a: Kinzler, R.J., 1997: Journal of Geophysical Research, v. 102, pp. 853-874.

b: Thirlwall, M. et al., 1994: Journal of Petrology, v. 35, pp. 839879.

1: McKenzie, D. and O’Nions, R.K., 1991: Journal of Petrology, v. 32, pp. 1021-1091.

2: Shimizu, H., 1980: Geochemical Journal, v. 14, pp. 185-202.

3: Kennedy, A.K. et al., 1993: Earth and Planetary Science Letters, v. 115, pp. 177-195, doi:10.1016/0012-821X(93)90221-T.

4: Ewart, A. and Griffin, W.L., 1994: Chemical Geology , v. 117, pp. 251-284, doi: 10.1016/0009-2541(94)90131-7.

5: Keleman, P.B. and Dunn, J.T., 1992: EOS, Transactions of the American Geophysical Union, v. 73, pp. 656-657.

6: Green, T. et al., 2000: Lithos, v. 53, pp. 165-187, doi: 10.1016/S0024-4937(00)00023-2.

7: Klemme, S. et al., 2006: Chemical Geology, v. 234, pp. 251-263, doi: 10.1016/j.chemgeo.2006.05.005.

8: Adam, J. and Green, T., 2006: Contributions to Mineralogy and Petrology, v. 152, pp. 1-17.

9: Hart, S.R. and Dunn, T., 1993: Contributions to Mineralogy and Petrology, v. 113, pp. 1-8.

10: Zack, T. et al., 1997: Neues Jahrbuch fur Mineralogie, Abhirchen 172, pp. 23-41.

11: Elkins, L., et al. (2008). Earth and Planetary Science Letters 265, pp. 270-286. doi: 10.1016/j.eps1.2007.10.034. 